\title{
Material Databases and Validation in Modelling the Structure of Castings Using the Cellular Automaton Method
}

\author{
Jakub Hajkowski ${ }^{1, *(\mathbb{D})}$, Robert Sika ${ }^{1}$, Michał Rogalewicz ${ }^{2}$, Paweł Popielarski ${ }^{1}{ }^{\circledR}$, Waldemar Matysiak ${ }^{1}$ \\ and Stanislaw Legutko ${ }^{3}$ (1)
}

1 Division of Foundry and Plastic Working, Institute of Materials Technology, Faculty of Mechanical Engineering, Poznan University of Technology, 3 Piotrowo St., 60-965 Poznan, Poland; robert.sika@put.poznan.pl (R.S.); Pawel.Popielarski@put.poznan.pl (P.P.); waldemar.matysiak@put.poznan.pl (W.M.)

2 Division of Production Engineering, Institute of Materials Technology, Faculty of Mechanical Engineering, Poznan University of Technology, 3 Piotrowo St., 60-965 Poznan, Poland; michal.rogalewicz@put.poznan.pl

3 Division of Technology Planning, Institute of Mechanical Technology, Faculty of Mechanical Engineering, Poznan University of Technology, 3 Piotrowo St., 60-965 Poznan, Poland; stanislaw.legutko@put.poznan.pl

* Correspondence: jakub.hajkowski@put.poznan.pl; Tel.: +48-61-665-2460

Citation: Hajkowski, J.; Sika, R.; Rogalewicz, M.; Popielarski, P.; Matysiak, W.; Legutko, S. Material Databases and Validation in Modelling the Structure of Castings Using the Cellular Automaton Method. Materials 2021, 14, 3055. https://doi.org/10.3390/ma14113055

Academic Editor: Wolfram Volk

Received: 7 May 2021

Accepted: 1 June 2021

Published: 3 June 2021

Publisher's Note: MDPI stays neutral with regard to jurisdictional claims in published maps and institutional affiliations.

Copyright: (C) 2021 by the authors Licensee MDPI, Basel, Switzerland. This article is an open access article distributed under the terms and conditions of the Creative Commons Attribution (CC BY) license (https:/ / creativecommons.org/licenses/by/ $4.0 /)$.
Abstract: The paper presents the scope of applicability and the usefulness of the method of predicting crystalline structure of castings using a commercially available system called Calcosoft CAFE. The influence of individual values of the parameters of the thermal model and the model predicting the structure (phenomenon of nucleation and crystal growth), and the method of interpretation of the results were identified. In simulation studies, it is important to use reliable and validated material database, under appropriate conditions. It is necessary to predict the properties of castings with a comprehensive, new and practical approach to modelling the formation of phase components of structure in terms of both macroscale and microscale phenomena (Multiscale and Multiphysics). Therefore, in this paper, the experimental-simulation validation of the CAFE code was undertaken. The tests were carried out on castings solidifying under various heat transfer conditions controlled by mould materials such as: a homogenous mould made of moulding sand, moulding sand with chill, and mould made of insulating mass with chill. These conditions directly influence the structure formation. The method of validation of the structure was determined in terms of its three parameters, i.e., the degree of refinement of the crystals, the location of the columnar-to-equiaxed transition zone-CET and the angle of the crystals. The above tests enabled to extend the content of databases, which often lack the necessary values of parameters used in modelling, e.g., crystallization of a specific alloy under given conditions (sand casting, chills or laser surface treatment). On this basis, the basics of correlating the simulation results on a micro- and macroscale were generalized, the limits of the application of individual parameters (mould, alloy materials) and their impact on the structure formation were determined. It resulted in the extension of the database for simulation calculations.

Keywords: micromodeling; microstructure; cellular automaton; database; aluminum alloys

\section{Introduction}

The development of computer techniques and IT science in connection with the broadening of knowledge about casting processes has led to great progress in the field of simulation of technological processes in the cast-mould system [1,2]. Virtualization plays a steadily increasing role in the design of mechanical engineering technologies.

Currently, there are few scientific and technical fields that do not use the term "modelling", which means integration with numerical simulation. For the last thirty years, there has been an increasing number of publications, reviews and studies dealing only with these issues [1-6]. They can be found in the fields of solid mechanics, fluid mechanics, heat transfer, calculations of material structure formation, stress development, etc. The 
studies in which modelling and computer support have a dimension integrated with a real process, even if they describe complex particle phenomena, have the greatest value for foundry technology, otherwise, the scientific works are detached from the context of the application, which makes them hardly or completely not useful as supporting computer codes in foundry studies.

The main purpose of using simulation in casting processes with models in their basic coupled configuration (Navier-Stokes and Fourier-Kirchhoff) is to predict discontinuities in the casting as precisely as possible. This mainly concerns shrinkage defects (voids, porosity) $[7,8]$, the level of acceptability of which is set by the customer in the acceptance conditions, in accordance with the principles of the "tolerance of damage" approach. It is confirmed by results of an inspection using non-destructive testing (NDT) methods, commonly used in loss-free technologies [9]. Still, despite the passage of many years of operation of these two basic model configurations of simulation systems and experience in their application, more perfect prediction algorithms are still being sought [1,10-12]. These algorithms are assigned to the dynamics of solid phase growth and the flows between the elementary volumes of the casting, ascribed to the elements of the discrete division of the casting. These flows are known to be caused by shrinkage phenomena during solidification and the related local demand for liquid/solid-liquid metal. The balance of demand, local flows and grain nucleation and growth phenomena are modelled differently by individual simulation system creators [1-5,12-30].

It is crucial in the simulation of the phenomena forming the crystallization and solidification of the alloy to predict not only these phenomena on a macroscale resulting from the variability of temperature fields, but also to extend this prediction with a microstructure and segregation of the solute $[26,28]$. By introducing micromodelling algorithms (modules) from the Multiscale and Multiphysics family, it is possible to simulate the formation of primary grains and even the texture (columnar, equiaxed) of dendrites. In this method utilized for the crystallization model, the physical phenomena of nuclei formation (nucleation process) and their growth must come to the fore. An obvious advantage of this approach is that it represents a more realistic model approach to the local (grain scale) release of latent solidification heat depending on the local undercooling of the liquid alloy $[13,19,25,26]$, providing an opportunity for a better virtual look at the phenomena and comparing the results with the actual structure parameters.

Predicting the structure can be conducted with the use of simulation systems by means of coupled hard and soft modelling approaches. Hard models, i.e., those based on physical laws and the differential equations describing them, do not offer a satisfactory approach to a phenomenon as complex as the crystallization process. Therefore, it is necessary to look for solutions in the area of modelling in Multiscale and Multiphysics $[1,2,6,16]$. Systems of this type include the issues of several physical and/or physicochemical phenomena within one coupled model taking into account the discrete division scale, e.g., the most obvious in material technologies is macro-micro modelling. The aim is to try to reflect the real process as comprehensively as possible. However, this creates new validation tasks that must be undertaken in parallel with the creation of models intended for coupling. The inclusion of soft models seems to be indispensable for the "Multiscale" modelling problem to find solutions useful in foundry practice.

Therefore, in this work, for the experimental and simulation validation, the coupled macro-micro code Calcosoft-Cellular Automaton Finite Element (CAFE) (Ecole Politechnique Federale de Lausanne EPFL, Lausanne, Switzerland and ESI Group, Paris, France) $[1,13,16,19,22,23,31,32]$ was applied, which is considered to be one of the best simulation codes for predicting the formation of columnar and equiaxed crystals in castings. This method has been developed since 1990 and consists in the primary discretisation of the casting by the finite element (FE) method-(heat transfer modelling-macromodel) and the secondary discretization of the modelled solid-liquid phase space, with the formation of cells with very small dimensions, of the value of $10^{-4}-10^{-6} \mathrm{~m}$ (modelling of structure formation phenomena using a cellular automaton-CA-micromodel). Hence, this method 
was designated by its creators from Ecole Politechnique Federale de Lausanne-EPFL with the acronym CAFE [21,23].

\section{State of the Art}

According to Rappaz [13], the modelling scales can be formally divided into four groups, referring to four generations of simulation (modelling) systems covering the issues of crystallization and solidification of castings: macro-, meso-, micro-, and nano- [17-20].

Unfortunately, most of the described models from the Multiphysics family $[1,2,14,15,27]$ in terms of predicting the structure formation refer to the local modelling of phenomena for very small, separated areas, without and reference to the entire casting and mould. For example, the growth of only single equiaxed crystals or at most a group of several crystals (dendrites) is generated, mostly often in two-dimensional way, without reference to the real process conditions, which is a necessary condition for practitioners and industrial realities [16]. The Calcosoft CAFE system tries to indicate the application direction in order to meet not only simple castings, but also those of a more complex shape.

Modelling of the structure of castings using the available simulation codes from the Multiscale/Multiphysics family is limited to single grains [1,4,15,18,29,30,33-39], e.g., in the form of a developed dendrite shape in 2D and 3-D space (dimension degree of the task influences on total cells number and computation time), or in the form of its simplified shape-primary tips inscribed into the structure of entire castings [22-24]. However, it includes the coupling of the macro- and microscopic levels. The macro level is related to the leading phenomenon-heat flow-while the micro level is related to the phenomena associated to the mechanisms of nucleation and growth of the grains (taking into account, for example, local distribution of the solute), and as a result generating the latent heat of solidification in proportions relevant to the grain volume increase. This enables to determine parameters such as: DAS1 - the distance between the axes of the primary dendrites (because cellular automata, CA, do not allow modelling the growth of secondary dendrite tips by generating pseudo-dendrites in the form of crystallite blocks with the accuracy to the CA cell size), the size of the crystallites, the location of the columnar-toequiaxed transition zone (CET).

In $[24,37]$ the cellular automaton method has been coupled with the finite difference method to solve the phenomena of solute diffusion. Lee et al. [24,37] and Nastac [40] added a more precise technique-front tracking with the release of the solid phase in each growing cell, which allows to distinguish not only the outline, but also the morphology of the dendrite taking into account higher-order tips (arms).

Another approach (using the possibilities offered by the algorithms of numerical solutions in relation to analytical solutions) is to the estimate the transition limit of columnar dendrites into equiaxed forms as presented in the paper [18,29]. The coupled model is based on the Fourier-Kirchhoff equation and on the diffusion equation for three areas: the solid phase, liquid phase in the space between the dendrite tips, and the liquid phase outside the dendrite; and on the equations describing nucleation (according to the hypothesis developed by Stefanescu [18] and the growth of dendrites according to models: Kurzthe growth of the dendrite tip, Hunt- the space between the first-order arms, Kurz and Fisher-the distance between the second-order arms).

Martorano et al. [41] proposed a different hypothesis for the mechanism of a columnarto-equiaxed transition zone (CET). The indicated model of directional crystallization is characterized by a certain temperature gradient. Equiaxed dendrites nucleate in the area below the temperature $\mathrm{T}_{\mathrm{N}}$, lower than the liquidus isotherm $\left(\mathrm{T}_{\mathrm{L}}\left(\mathrm{C}_{0}\right)\right)$ in an undercooled liquid phase with a concentration range of $\mathrm{C}$ above $\mathrm{C}_{0}$. According to the classical theory of the phenomenon, equiaxed dendrites growing before the columnar dendrites enrich the liquid phase with an solute "pushed" beyond the crystal, which obviously causes an increase in the concentration of the liquid phase $C_{1}$ above the initial concentration $C_{0}$.

In this model, considering the movement direction of the front (towards the casting axis), a linear concentration decrease $\left(C_{l}^{*}\right)$ was assumed in the liquid phase for the growth 
area of columnar crystals only, while with the appearance of equiaxed crystals, a faster decrease in concentration was assumed and it was described by a curvilinear correlation $C_{l}$.

Generalizing the shape of crystallites in the micro scale formed from the nuclei present and /or formed near the mould wall in the form of solid and gaseous (exogenous) inclusions and on the surface of other solid (endogenous) phases depends on the value and orientation of the temperature gradient at the crystallization front, the rate of shifting the crystallization front, and the concentration gradient of the dopant in the liquid phase, before the crystallization front [42-44].

Modelling of microstructure formation with the use of numerical methods is already permanently present in the issues of crystallization and solidification of aluminium and iron alloys. The aim is to predict casting structures with desired local properties, and this is a basic expectation. Most often, this prediction is an indirect inference (based on the temperature gradients and the cooling rate calculated during the simulation process) or with the application of deterministic models. The selected models are presented below. They are used to predict the structure on the scale of trial castings and those made with the use of special casting technologies, e.g., casting with directional crystallization of superalloys. These are models named after the methods of solving them: Phase-Field Method, Pseudo Front Taracking and Cellular Automaton Finite Element (CAFE) $[1,4,14,15,27,45-47]$. There are two versions of the CAFE code-2D and 3D-and both codes will be applied in the paper. The advantage of 3D code over 2D depends the possibility of predicting products of practically any shape. In 2D code prognosis are possible for simple shapes: plate, axisymmetric figures introducing specific boundary conditions of heat transfer. The disadvantage of $3 \mathrm{D}$ codes in relation to $2 \mathrm{D}$ is longer $\mathrm{CPU}$ time.

\section{Materials and Methods}

\subsection{Structure Prediction Using Pseudo Front Tracking (PFT) and Phase Field (PHF) Codes}

Two modules of the Calcosoft simulation code from the Multiphysics family: Pseudo Front Tracking (PFT) and Phase Field (PHF) [14] were developed with the intention of recreating the formation of a dendritic structure and relating to the local modelling of physical phenomena for very small areas (less than $1 \mathrm{~mm}^{2}$ ) and for a discrete division with a very small element size (microns) [43-45]. The assumptions made by the authors consisted in creating a coupling of models responsible for the growth of not only the primary arms, as is the case of the Calcosoft CAFE model described in detail in the next section, but also the secondary ones. As an example cited in the literature, the growth of single equiaxed crystals or at most a group of several crystals (dendrites) in 2D geometry taken out of the context of real conditions was presented [16].

The following selected parameter values were used to predict the structure using the Calcosoft PHF model: number of discrete division cells in the $x$ axis $=200$, in the $y$ axis $=200$, discrete division cell size $=1.25 \times 10^{-6} \mathrm{~m}, \mathrm{Cu}$ concentration $=2.2 \%$ (Figure 1).
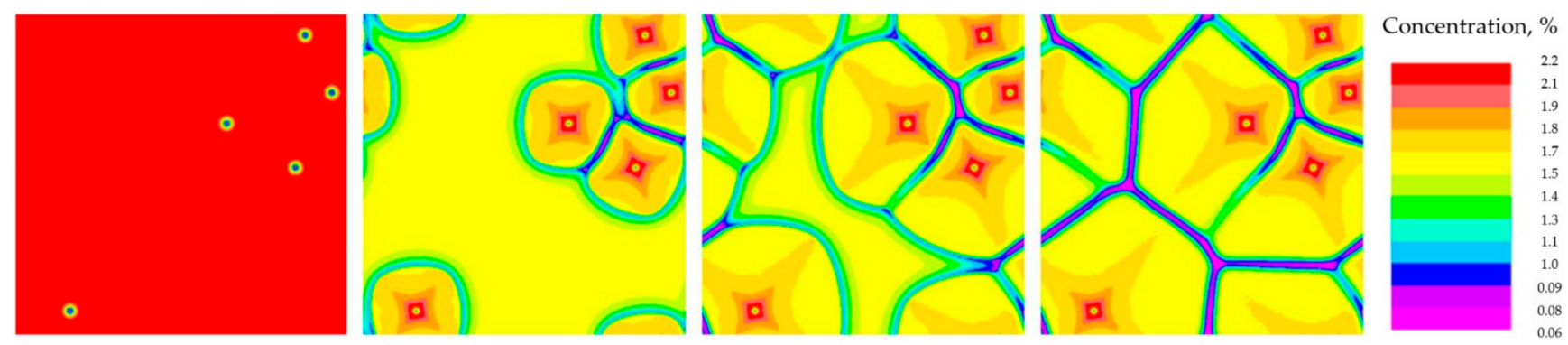

Figure 1. Sequence of 5-grains (simplified dendrites) growth for the simulation performed in the Calcosoft PHF (Phase Field Method) system, visible variation in solute concentration.

Two examples of test simulations using the Calcosoft PFT module are presented below. The tests were conducted for the growth of one grain (Figure 2) and 40 grains (Figure 3). In 
both cases the $\mathrm{AlCu} 2$ alloy was used and the parameter values as in the previous case. The aim was to compare with the Calcosoft PHF model.
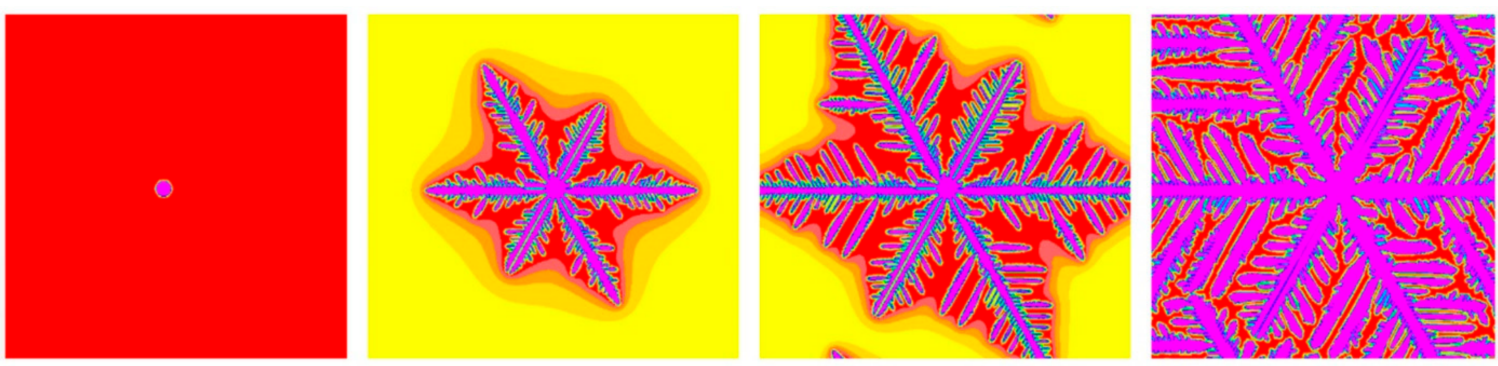

Concentration, \%

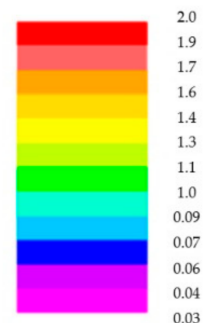

Figure 2. Sequence of one dendritic grain growth for the simulation performed in the Calcosoft system in the PFT (Pseudo Front Tracking) module.
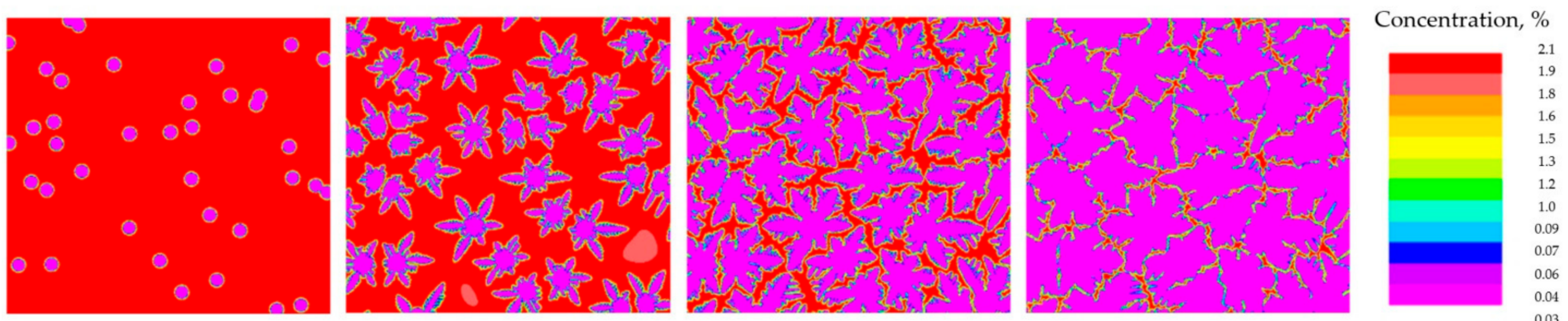

Figure 3. Sequence of growth of 40 dendritic grains for the simulation performed in the Calcosoft system in the PFT (Pseudo Front Tracking) module and the discretization grating with a size of $1.25 \times 10^{-6} \mathrm{~m}$.

The above examples of structure modelling models prove that it is impossible to obtain the transfer expected by practitioners of the method of structure formation virtualization into the real object. Therefore, in this work, the Calcosoft CAFE simulation code was used in further tests. It is an example of an effective combination of macro- and micro-modelling, which enables the prediction of the structure (columnar and equiaxed pseudo-dendrites) for quite complex-shaped castings. The postulates formulated with regard to subsequent micromodels should go in this direction. Moreover, the CAFE code, unlike the others, is a part of the commercial systems of both Calcosoft and Procast. The aforementioned aspects were the basis for the validation of the CAFE code.

\subsection{Description of the CAFE Model}

The virtualization of casting processes is one of the important directions of tests on the prediction of local casting properties. This consists of identifying the property gradient and indicating areas that can bear loads exceeding the allowable stresses, which are formally averaged out of caution due to the average structure and properties of the entire casting. One way to obtain reliable information about the local properties of the casting is by modelling the crystallization process.

Modelling the phenomena responsible for crystallization, i.e., the formation of the microstructure of metal alloys during the change of their state from liquid to solid (solidification, understood in the macro scale), depending on the physical conditions of this process, was initially developed based on deterministic models describing nucleation and growth of only equiaxed (globular) crystals. These models are characterized by many simplifications and limitations, described e.g., in [22,23,48-52]. For this reason, models using stochastic (probabilistic) methods began to be developed.

Among the described methods and systems, the algorithms of the Calcosoft system and its CAFE module method, which is also part of one of the leading simulation systems for casting technology-ProCAST, effectively function as an advanced tool that formally 
enables the implementation of structure prediction in the above-mentioned way. Therefore, in this work, the validation of this simulation code was undertaken.

\subsubsection{Crystal Nucleation}

Heterogeneous nucleation, as definitely dominant in technical alloys, occurs both in the bulk of the liquid and in the liquid region at the contact surface with the mould. In the discussed model, it is described by two views derived from the basics of statistics and indicates the nucleation sites that are activated when undercooling occurs. The authors $[23,48-50,52]$ proposed here the use of the normal Gaussian distribution (Figure 4) in such a way that the rate of grain formation with undercooled $\Delta \mathrm{T}$ in the bulk of liquid $d n_{v} / d(\Delta T)\left[\mathrm{m}^{-3} \mathrm{~K}^{-1}\right]$ or on the surface of the mould $d n_{s} / d(\Delta T)\left[\mathrm{m}^{-2} \mathrm{~K}^{-1}\right]$ is calculated from Equation (1):

$$
\frac{d n_{v(s)}}{d(\Delta T)}=\frac{n_{\max }}{\Delta T_{\sigma} \cdot \sqrt{2 \pi}} \exp \left[\frac{1}{2}\left(\frac{\Delta T-\Delta T_{m-(i)}}{\Delta T_{\sigma}}\right)^{2}\right]
$$

and the distribution function of this distribution, given by the following correlation, allows to calculate the actual number of active nuclei (2):

$$
n_{v(s)}(\Delta T)=\int_{0}^{\Delta T}\left[\frac{d n}{d(\Delta T)}\right]_{v(s)} \cdot d(\Delta T)
$$

where $\Delta T$-local undercooling calculated using the Fourier-Kirchhoff model, $\Delta T_{m-(i)}$ average undercooling value corresponding to the maximum nucleation intensity, $i=s$ (surface nucleation) or $i=v$ (bulk nucleation), an empirical characteristic parameter of the Gaussian distribution, $\Delta T_{\sigma}$-standard deviation of undercooling, an empirical characteristic parameter of the Gaussian distribution, $n_{\max }$ - theoretical maximum nuclei density which can be reached when all possible nucleation sites are activated during cooling, an empirical characteristic parameter of the Gaussian distribution $\left(\Delta T_{m-(i)}, \Delta T_{\sigma}\right.$ and $n_{\max }$ for a given alloy are determined experimentally, taking into account the knowledge about the sensitivity of Gaussian distribution to these parameters and quantitative metallography size and homogeneity of the grains after primary crystallization, determined a posteriori on the basis of metallographic tests), $d n_{v}$ - first derivative of grains number and $d(\Delta T)$ - first derivative of undercooling

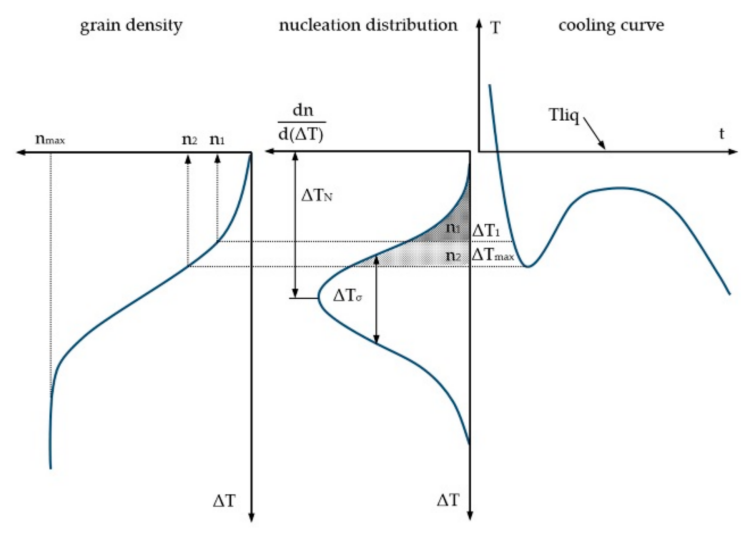

Figure 4. Distribution of nucleation sites and nuclei density on the mould surface $n_{\mathrm{s}}$ and in the bulk of liquid $n_{v}$.

The above remark is a clarification of the information provided by the authors of this concept $[23,48,49,53]$. Modelling heterogeneous nucleation using the CA procedure is relatively simple. Each nucleating cell is assigned a critical nucleation temperature (temperature below the liquidus equilibrium temperature). For liquids deep inside the casting (for CA cells that are not adjacent to the surface of the casting), undercooling is 
randomly generated according to the Gaussian normal distribution and is assigned to randomly selected cells.

As mentioned above, the parameters of heterogeneous nucleation for handling the Gaussian distribution (grain density, average temperature and standard deviation) must be analysed on the basis of the experimental results obtained from the trial casting test. Corresponding undercooling $\Delta \mathrm{T}_{v}{ }^{\text {nuc }}=\mathrm{T}_{\mathrm{L}}-\mathrm{T}_{v}{ }^{\text {nuc }}$ (where: $\mathrm{T}_{\mathrm{L}}$-liquidus temperature, $\mathrm{T}_{\mathcal{v}}{ }^{\text {nuc }}$ critical nucleation temperature) of predetermined nucleating cells is recorded. Two different Gaussian distributions are in use for the same alloy (for nucleation at the castmould or cast-environment surface and for nucleation in the bulk of alloy). If a cell is selected several times, then only one, lesser nucleation undercooling is used. If, during the time step, local undercooling $\Delta \mathrm{Tt} v$ of the given nucleating $v$ cell which was still liquid in the preceding time step will exceed the previously assigned nucleation undercooling $\Delta \mathrm{T}_{v}$ nuc, then a new grain will be created. The state index of this cell, which has a value of zero when it is in a liquid state, in this case takes a positive integer value, randomly selected from the fixed orientation class numbers $[23,46]$.

\subsubsection{Crystal Growth}

The main diagonals of the octahedron correspond to the crystallographic orientations $<100\rangle$, along which tips of metal dendrite with a regular centred wall grow in a preferred way. Their increase is calculated by integrating over time the growth equation of dendrite tips described by Kurz formula [23,48]. Therefore, in the time step $\delta t$ used to integrate the growth rate of the dendrite tips, the increase in the length of the diagonals of the octahedron associated with the v cell (Figure 5) $\Delta R_{v}$ is described by Equation (3):

$$
\Delta R_{v}=v\left(\Delta T_{v}\right) \cdot \delta t
$$

where: $v\left(\Delta T_{v}\right)=a_{2} \cdot \Delta T^{2}+a_{3} \cdot \Delta T^{3}$ is the dendrite tip growth rate calculated for a given undercooling $\Delta T_{v}$ in the cell $v$.

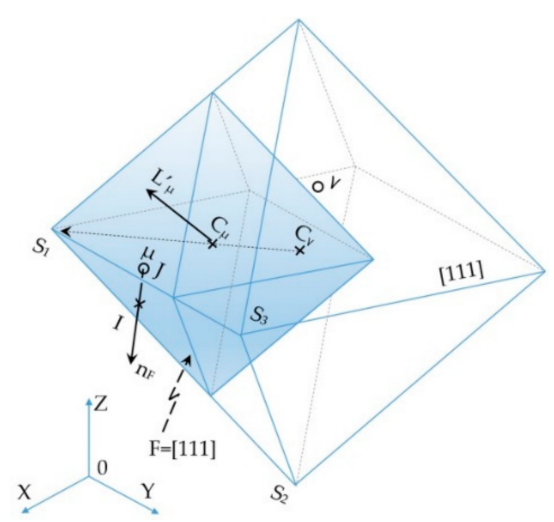

Figure 5. Diagram of cell growth in the CAFE 3D model.

\subsection{Methodology of Experimental and Simulation Tests}

\subsubsection{Assumption and Methodology of Experimental Tests}

The cylindrical shape of the casting was adopted for the tests due to its axial symmetry and the resulting facilitations in the formulation of the thermal model and in the description of the correlation of the crystal structure parameters with the thermal parameters of the cast-mould system. The experimental studies were conducted on AlSi7Mg alloy castings. with the chemical composition presented in Table 1 with a diameter of $70 \mathrm{~mm}$ and height of $220 \mathrm{~mm}$, made in three types of moulds: homogeneous moulding sand (Q-Q), a moulding sand $(\mathrm{Q})$ with a copper chill $(\mathrm{Ch})$ located on the bottom side of the cylindrical casting, and in the mould of insulating mass (HI) with an analogously placed copper chill (Ch). 
Table 1. Chemical composition of the alloy to be tested (AlSi7Mg).

\begin{tabular}{ccccccccc}
\hline Element & $\mathbf{S i}$ & $\mathbf{M g}$ & $\mathbf{C u}$ & $\mathbf{F e}$ & $\mathbf{T i}$ & $\mathbf{M n}$ & $\mathrm{Zn}$ & $\mathrm{Al}$ \\
\hline Concentration $\%$ & 6.86 & 0.3 & 0.01 & 0.1 & 0.01 & 0.01 & 0.01 & bal. \\
\hline
\end{tabular}

The parameters of the resulting structure will be described (for solid solution dendrites $\alpha$ and especially the location of the columnar-to-equiaxed transition zone-CET). The number of equiaxed crystals per unit area was also estimated.

A method of instrumentation of the mould (distribution of thermocouples) was developed, which allowed for the quantitative identification of thermal conditions, and then enabled the validation of the model used in the simulation of the crystallization process. The crystallization model used (Calcosoft, CAFE module) incorporates only the growth of solid solution dendrites $\alpha$ (as CAFE does not incorporate the crystallization of the eutectic phase and the intermetallic phases). Possible estimation of the presence of the eutectic phase can only concern the zones between the simplified blocks of dendritic crystals. However, this is not a direct result of the virtualization of the crystallization process of all phases of this alloy. The intensity of heat abstraction from the casting to the mould and/or chill, and thus the casting solidification process, was defined by the local solidification times of the $\alpha$ phase determined on the basis of the recorded cooling curves.

\subsubsection{Assumption and Methodology of Simulation Tests}

As mentioned above, the Calcosoft system with the CAFE-3D module was used in the simulation studies to predict the pseudo-dendritic structure. The simulation tests concerned a cylinder-shaped casting with a diameter $(\phi)$ of $70 \mathrm{~mm}$. Firstly, the energy validation of the real and virtual solidification time compliance was performed by interpreting the cooling curves on the basis of their first derivatives. The validation concerned only the solidification of the $\alpha$ phase, as the Calcosoft CAFE model considers only the growth of this phase and formally assumes that it fills the entire space of the structure, including the eutectic phase that actually surrounds it.

Therefore, the pseudo-dendritic virtual structure (in the form of compact pseudograins) should be treated as the $\alpha$ phase dendrite filled in the central part of the pseudograin, and its environment is the eutectic phase invisible on the virtual structure. Estimation of the proportions of both phases in a pseudo-grain can be performed using the classical lever rule (assuming thermodynamic equilibrium).

In the next stage, tests related to the sensitivity of the CAFE model was conducted, i.e., by checking the impact of changing the values of individual parameters available in the CAFE model on the position of columnar-to-equiaxed transition zone and the grain size (pseudo-dendrites). The ranges of parameter values for this procedure were selected. Only one parameter value was variated at once in these studies.

Validation studies related to structure prediction consisted in the analysis of the compliance of the CET zone location and grain size. The problem of the influence of the variability of the model parameters on the orientation of pseudo-dendrites in the casting space was also analysed. The values of the orientation angles of the columnar grain blocks from the calculation are marked by colour differentiation.

\subsubsection{Experimental and Simulation Validation}

In the simulation calculations, variants of selected values of thermophysical parameters and parameters related to the model of microstructure formation were used. Table 1 presents their values for the tests of the casting solidifying in the following moulds: homogeneous moulding sand (Q-Q), of moulding sand with a chill (Q-Ch), of an insulating mass with a chill (HI-Ch). The diagram of the mould, its real view and the axial section of the virtual mould with the visible FEM discrete mesh are shown in Figure 6. 


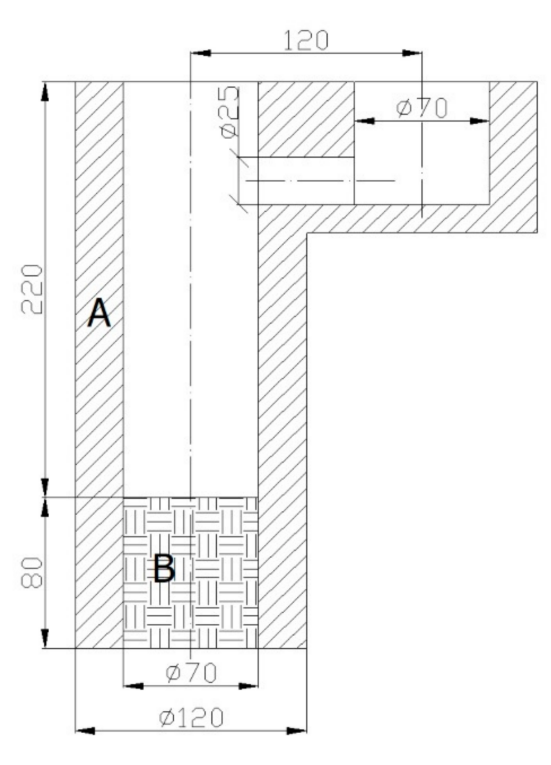

(a)

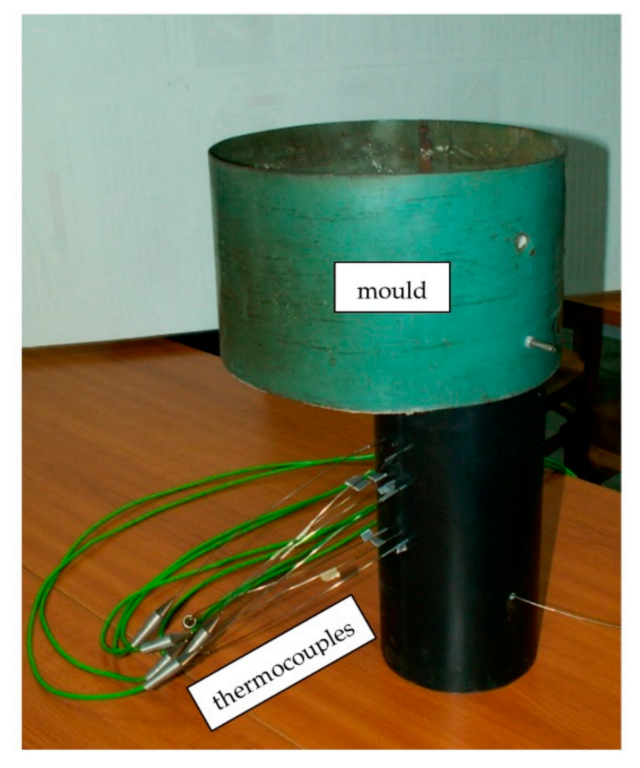

(b)

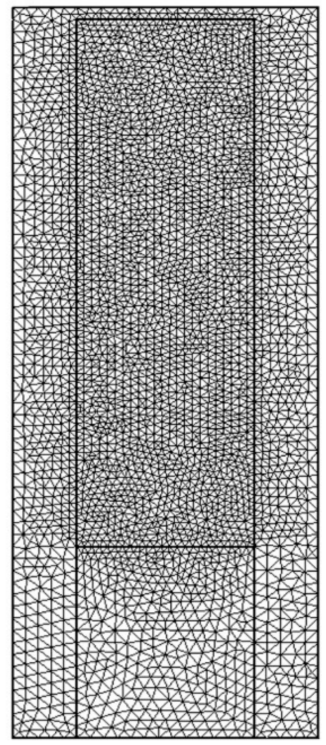

(c)

Figure 6. Casting mould: (a) mould diagram (A—moulding sand (Q) or insulating mass mould (HI) material B-moulding sand (Q) or chill (Ch)), (b) mould view, (c) virtual mould with FEM mesh.

It should be added that the introduction in the CAFE-3D module of modelling parameters for the casting crystallization including the segregation of the solute alloy component (Si) is an important distinguishing feature of the model coupling. It is based on the fact that the heat generation of crystallization is related to the liquidus temperature updated at each time step during the simulation, in a function of the local concentration of the solute. The concentration variation is made according to the Scheil model (Equation (4)). It assumes that the solute does not diffuse in the solid phase, but that it is fully distributed in the liquid phase:

$$
C_{S}=k C_{0}\left(1-f_{S}\right)^{k-1}
$$

where $k$-partition coefficient $\left(k=C_{S} / C_{L}\right), C_{S}$ - solute concentration in the solid phase, $C_{L}-$ solute concentration in the liquid phase, $C_{0}$-initial solute concentration and $f_{S}$ - fraction of solid.

The analysis and selection of thermophysical coefficients and the values of the parameters necessary for empirical correlations (nucleation and growth) required for the simulation, leading to good compliance of the virtually predicted structure with the structure from the experiment, are easier in terms of conscious selection of the abovementioned parameters when their impact on the predicted structure is known (model sensitivity). Table 2 lists the ranges of parameter values that were determined as a result of simulation tests. They are a result of many series of simulations under various thermal conditions in the cast-mould system.

Table 2. Ranges of parameter values used for simulation.

\begin{tabular}{cccc}
\hline Parameter & Name & Value & Unit \\
\hline \multicolumn{4}{c}{ Changing-value Parameters } \\
\hline \multicolumn{4}{c}{ homogenous silica sanding mould } \\
\hline$\lambda_{\mathrm{Q}}$ & heat conduction & $0.5-1.5$ & $\mathrm{~W} / \mathrm{mK}$ \\
$\alpha_{\text {cast-mould }}$ & heat transfer coefficient $(\mathrm{HTC})$ & $500-20,000$ & $\mathrm{~W} / \mathrm{m}^{2} \mathrm{~K}$ \\
$\Delta \mathrm{T}_{\mathrm{m}-\mathrm{s}-\mathrm{Q}}$ & undercooling on the mould surface & $\mathrm{K}$ & $\mathrm{K}$ \\
$\Delta \mathrm{T}_{\mathrm{m}-\mathrm{v}-\mathrm{Q}}$ & undercooling in the bulk of liquid & $2-5$ & 10 \\
$\mathrm{n}_{\mathrm{s}-\mathrm{Q}}$ & nuclei number on the mould surface & $1 \times 10^{4}-1 \times 10^{8}$ & $1 / \mathrm{m}^{2}$ \\
\hline
\end{tabular}


Table 2. Cont.

\begin{tabular}{|c|c|c|c|}
\hline Parameter & Name & Value & Unit \\
\hline \multicolumn{4}{|c|}{ Changing-value Parameters } \\
\hline $\mathrm{n}_{\mathrm{v}}$ & nuclei number in the bulk of liquid & $1 \times 10^{5}-1 \times 10^{10}$ & $1 / \mathrm{m}^{3}$ \\
\hline$a_{3}$ & kinetic coefficient & $1.49 \times 10^{-8}-1.49 \times 10^{-5}$ & $\mathrm{~ms}^{-1} \mathrm{~K}^{-3}$ \\
\hline \multicolumn{4}{|c|}{ double-material silica sanding mould with chill } \\
\hline$\lambda_{\mathrm{Q}}$ & heat conduction & $0.5-1.5$ & $\mathrm{~W} / \mathrm{mK}$ \\
\hline$\alpha_{\text {cast-chill }}$ & heat transfer coefficient (HTC) & $100-800$ & $\mathrm{~W} / \mathrm{m}^{2} \mathrm{~K}$ \\
\hline$\Delta \mathrm{T}_{\mathrm{m}-\mathrm{v}-\mathrm{Q}}$ & undercooling in the bulk of liquid & $1.5-5$ & $\mathrm{~K}$ \\
\hline $\mathrm{n}_{\mathrm{v}-\mathrm{Q}}$ & nuclei number in the bulk of liquid & $1 \times 10^{6}-1 \times 10^{9}$ & $1 / \mathrm{m}^{3}$ \\
\hline $\mathrm{a}_{3}$ & kinetic coefficient & $2 \times 10^{-7}-2 \times 10^{-5}$ & $\mathrm{~ms}^{-1} \mathrm{~K}^{-3}$ \\
\hline \multicolumn{4}{|c|}{ double-material silica sanding mould with chill } \\
\hline$\lambda_{\mathrm{HI}}$ & heat conduction & $0.3-1.5$ & $\mathrm{~W} / \mathrm{mK}$ \\
\hline$\alpha_{\text {cast-chill }}$ & heat transfer coefficient (HTC) & $50-1000$ & $\mathrm{~W} / \mathrm{m}^{2} \mathrm{~K}$ \\
\hline$\Delta \mathrm{T}_{\mathrm{m}-\mathrm{s}-\mathrm{HI}}$ & undercooling on the mould surface & $2.5-10$ & K \\
\hline$\Delta \mathrm{T}_{\mathrm{m}-\mathrm{s}-\mathrm{ch}-\mathrm{HI}}$ & undercooling on the chill surface & $5-20$ & $\mathrm{~K}$ \\
\hline$\Delta \mathrm{T}_{\mathrm{m}-\mathrm{v}-\mathrm{HI}}$ & undercooling in the bulk of liquid & $0.5-8$ & $\mathrm{~K}$ \\
\hline $\mathrm{n}_{\mathrm{s}-\mathrm{HI}}$ & nuclei number on the mould surface & $1 \times 10^{5}-1 \times 10^{8}$ & $1 / \mathrm{m}^{2}$ \\
\hline $\mathrm{n}_{\mathrm{s}-\mathrm{CH}}$ & nuclei number on the chill surface & $1 \times 10^{5}-1 \times 10^{8}$ & $1 / \mathrm{m}^{2}$ \\
\hline $\mathrm{n}_{\mathrm{v}-\mathrm{HI}}$ & nuclei number in the bulk of liquid & $1 \times 10^{7}-1 \times 10^{10}$ & $1 / \mathrm{m}^{3}$ \\
\hline $\mathrm{a}_{3}$ & kinetic coefficient & $6.5 \times 10^{-8}-6.5 \times 10^{-5}$ & $\mathrm{~ms}^{-1} \mathrm{~K}^{-3}$ \\
\hline \multicolumn{4}{|c|}{ Fixed-value parameters } \\
\hline$\alpha_{\text {cast-mould }}$ & heat transfer coefficient on the casting-mould interface & 10,000 & $\mathrm{~W} / \mathrm{m}^{2} \mathrm{~K}$ \\
\hline$\alpha_{\text {mould-ambient. }}$ & heat transfer coefficient on the mould-ambient interface & 20 & $\mathrm{~W} / \mathrm{m}^{2} \mathrm{~K}$ \\
\hline $\mathrm{C}_{\mathrm{pQ}}$ & heat capacity of mulding sand & 1500 & $\mathrm{~kJ} / \mathrm{m}^{3} \mathrm{~K}$ \\
\hline $\mathrm{C}_{\mathrm{pHI}}$ & heat capacity of isolating mulding material & 587 & $\mathrm{~kJ} / \mathrm{m}^{3} \mathrm{~K}$ \\
\hline$\sigma_{\Delta \mathrm{Ts}-\mathrm{Q} / \mathrm{HI}}$ & standard deviation on the mould surface & 0.4 & K \\
\hline$\sigma_{\Delta \mathrm{Ts}-\mathrm{Ch}}$ & standard deviation on the chill surface & 0.4 & $\mathrm{~K}$ \\
\hline$\sigma_{\Delta \mathrm{Tv}}$ & standard deviation in the bulk of liquid & 0.4 & $\mathrm{~K}$ \\
\hline$\Delta \mathrm{T}_{\mathrm{m}-\mathrm{s}-\mathrm{Q}}$ & undercooling on the mould surface (Q-Ch) & 5 & $\mathrm{~K}$ \\
\hline$\Delta \mathrm{T}_{\mathrm{m}-\mathrm{s}-\mathrm{ch}-\mathrm{Q}}$ & undercooling on the chill surface (Q-Ch) & 15 & $\mathrm{~K}$ \\
\hline$n_{s-Q}$ & nuclei number on the mould surface (Q-Ch) & $1 \times 10^{6}$ & $1 / \mathrm{m}^{2}$ \\
\hline $\mathrm{n}_{\mathrm{s}-\mathrm{Q}}$ & nuclei number on the chill surface (Q-Ch) & $1 \times 10^{7}$ & $1 / \mathrm{m}^{3}$ \\
\hline
\end{tabular}

The thermophysical parameters of the mould that have a decisive influence on the intensity of heat receive from the liquid phase are $\lambda, \mathrm{c}$ and $\rho$ of the moulding sand and the heat transfer coefficient- $\alpha$ on the casting-mould interface (casting-chill).

The simulation tests of the cooling curves were conducted by varying the $\lambda$ values of the moulding masses and $\alpha$ cast-mould (casting-chill), and the remaining values of the thermophysical parameters of the thermal model were assumed to be of constant value:

- heat capacity of AlSi alloy of the solid phase $-\mathrm{c} \rho_{\mathrm{Al}-\mathrm{sol}}=2700 \mathrm{~kJ} /\left(\mathrm{m}^{3} \mathrm{~K}\right)$, of the liquid phase $\mathrm{c} \rho_{\mathrm{Al}-\mathrm{liq}}=3483 \mathrm{~kJ} /\left(\mathrm{m}^{3} \mathrm{~K}\right)$;

- thermal conductivity of alloy of the solid phase $\lambda_{\mathrm{Al}-\mathrm{sol}}=130 \mathrm{~W} /(\mathrm{mK})$, of the liquid phase $\lambda_{\mathrm{Al}-\text { liq }}=90 \mathrm{~W} /(\mathrm{mK})$;

- latent heat of solidification $\mathrm{L}=1.131 \times 10^{9} \mathrm{~J} / \mathrm{m}^{3}$; heat capacity of the moulding sand $-\mathrm{c} \rho_{\mathrm{Q}}=1500 \mathrm{~kJ} /\left(\mathrm{m}^{3} \mathrm{~K}\right)$;

- heat capacity of the insulating mass- $\mathrm{c} \rho_{\mathrm{HI}}=587 \mathrm{~kJ} /\left(\mathrm{m}^{3} \mathrm{~K}\right)$; heat capacity of the copper chill- $\mathrm{c} \rho_{\mathrm{Ch}-\mathrm{Cu}}=3300 \mathrm{~kJ} /\left(\mathrm{m}^{3} \mathrm{~K}\right)$ and thermal conductivity of the chill $\lambda_{\mathrm{Ch}-\mathrm{Cu}}=390 \mathrm{~W} /(\mathrm{mK})$ and the following parameters necessary to enter into the Scheil model (Equation (4)) and the solid phase increase generation model:

- pure aluminium (Al) melting point- $660^{\circ} \mathrm{C}$,

- $\quad$ eutectic temperature $\mathrm{T}_{\text {eut }}=572{ }^{\circ} \mathrm{C}$, 
- initial solute concentration $(\mathrm{Si}) \mathrm{c}_{0}=7 \%$ and the angle of the liquidus line slope $\mathrm{m}=-6.85^{\circ}$.

\section{Results}

The results of the tests on the influence of the parameter values in the CAFE model on CET and crystal size $d_{a v}$ were analysed on the basis of virtual structures for solidifying castings in the tested three configurations of moulds: Q-Q, Q-Ch and HI-Ch.

Analysis of the impact of the CAFE-3D model parameter values on CET and the average crystal size (pseudo-grains) $d_{a v}$ was determined from the Equation (5):

$$
d_{a v}=\frac{4 n_{L}}{\pi \cdot n_{S}}
$$

where $n_{L}$-number of intersections of grains per unit length and $n_{S}$-number of grains per unit area, which has been described separately for each material combination of the mould.

For each of the three variants of the mould configurations, the virtual structure best fitted to the experimental one is presented.

\subsection{Validation of the CAFE-3D Model on the Basis of the Casting Solidifying in the Q-Q Mould}

The analysed parameters of the virtual structure of the casting made in the Q-Q mould are subject to the following influences:

- in the thermal model—an increase in the thermal conductivity coefficient $\lambda$ (mould) from 0.5 to $2.0 \mathrm{~W} /(\mathrm{mK})$ causes an increase in the CET zone in the casting layer near the mould surface by approx. $10 \mathrm{~mm}$, with no significant influence of $\lambda$ on the crystal size $d_{a v}$ by approx. $0.1 \mathrm{~mm}$,

- $\quad$ in the thermal model —an increase in the heat transfer coefficient (cast-mould) $\alpha_{\text {cast- } Q}$ from 100 to a high value of $10,000 \mathrm{~W} /\left(\mathrm{m}^{2} \mathrm{~K}\right)$ does not significantly affect the position of CET (imperceptible variability in the near-surface layer of the casting) and $d_{a v}$, which is the result of the dominant effect of thermal resistance resulting from the presence of the moulding sand layer,

- in the nucleation model-undercooling in the bulk of the liquid phase $\Delta \mathrm{T}_{\mathrm{m}-\mathrm{v}}$ in the range from 2 to $5{ }^{\circ} \mathrm{C}$ has no effect on CET and slightly increases the $d_{a v}$ by approx. $0.13 \mathrm{~mm}$, only above this value of undercooling a longer CET zone begins to form, reaching a value variation of approx. $35 \mathrm{~mm}$ applying $10^{\circ} \mathrm{C}$ and an increase of the grain size $\mathrm{d}$ av by approx. $2 \mathrm{~mm}$,

- in the nucleation model-increase in nuclei density in the bulk of the liquid phase $\mathrm{n}_{\mathrm{v}}$ from $1 \times 10^{5}$ to $1 \times 10^{9}, \mathrm{~m}^{-3}$ has a large impact on reducing CET by approx. $23 \mathrm{~mm}$ and $\mathrm{d}_{\mathrm{av}} 4.7 \mathrm{~mm}$,

- in the growth model-increase in the value of the kinetic coefficient $\mathrm{a}_{3}$ in the pseudodendrite growth rate equation from $1.5 \times 10^{-8}$ to $1.5 \times 10^{-5} \mathrm{~ms}^{-1} \mathrm{~K}^{-3}$ causes a large increase in CET by approx. $40 \mathrm{~mm}$ and $\mathrm{d}_{\mathrm{av}}$ of approx. $3.46 \mathrm{~mm}$.

Comparison of the virtual structure with the real one (Figure 7), the results of the average grain size (Table 3), and the distribution of the grain surface share (Figure 8), indicate a satisfactory match in the near-surface layer and the rest of the casting.

Table 3. The values of the parameters of the Q-Q casting structure (Figure 7).

\begin{tabular}{|c|c|c|c|c|c|}
\hline Cross Section & & Virtual & cture & & Exp. Structure \\
\hline Structure Parameters-CAFE & $\begin{array}{l}\mathrm{Z}=44 \mathrm{~mm} \\
\text { Crosswise }\end{array}$ & $\begin{array}{l}\mathrm{Z}=88 \mathrm{~mm} \\
\text { Crosswise }\end{array}$ & $\begin{array}{c}\mathrm{Z}=116 \mathrm{~mm} \\
\text { Crosswise }\end{array}$ & $\mathrm{Y}=0 \mathbf{m m}$ & $\begin{array}{l}\mathrm{Z}=44 \mathrm{~mm} \\
\text { Crosswise }\end{array}$ \\
\hline Total grain number $(\mathrm{Nb})$ & 384 & 353 & 357 & 1321 & 356 \\
\hline Grains density on mould surface, $1 / \mathrm{m}^{2}$ & 99811 & 91754 & 92793 & 85779 & 92520 \\
\hline Average grain size $\mathrm{d}_{\mathrm{av}}, \mathrm{mm}$ & 5.0 & 5.2 & 5.2 & 5.5 & 5.2 \\
\hline
\end{tabular}




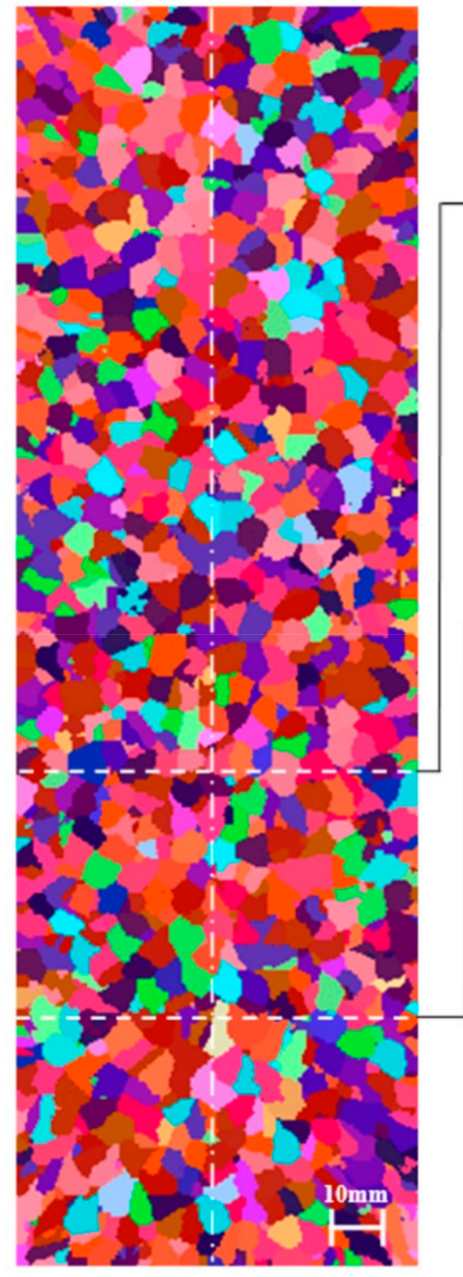

(a)

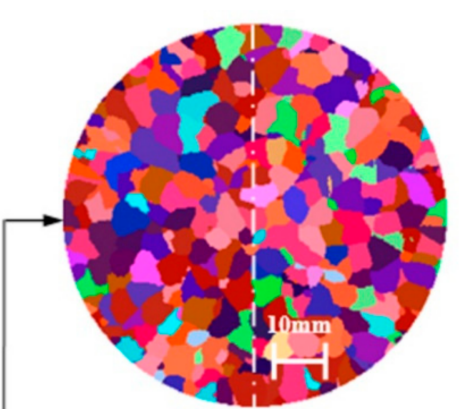

(d)

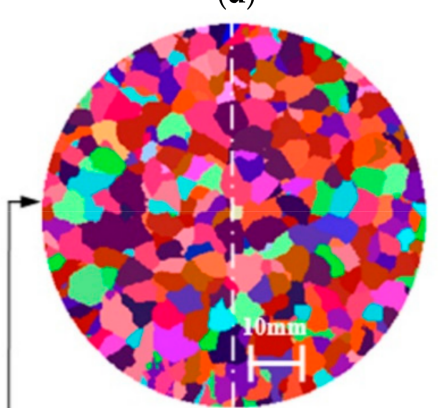

(c)

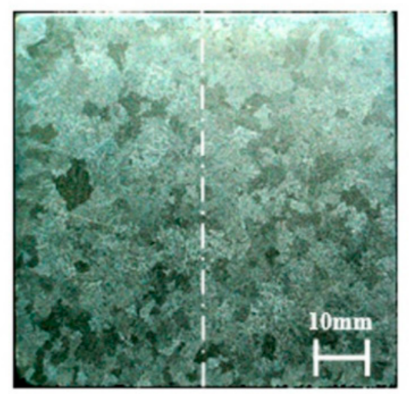

(b)

\begin{tabular}{|c|c|c|c|c|c|c|}
\hline 0 & 1 & 2 & 3 & 4 & 5 & 6 \\
\hline 7 & 8 & 9 & 10 & 11 & 12 & 13 \\
\hline 14 & 15 & 16 & 17 & 18 & 19 & 20 \\
\hline 21 & 22 & 23 & 24 & 25 & 26 & 27 \\
\hline 28 & 29 & 30 & 31 & 32 & 33 & 34 \\
\hline 35 & 36 & 37 & 38 & 39 & 40 & 41 \\
\hline 42 & 43 & 44 & 45 & 46 & 47 & 48 \\
\hline 49 & 50 & 51 & 52 & 53 & 54 &
\end{tabular}

Figure 7. Setting of structures for casting solidifying in a homogenous mould made of moulding sand (Q-Q): (a) virtual structure (longitudinal section), (b) real structure (longitudinal section), (c) virtual structure in height of $44 \mathrm{~mm}$ from the base of the cylinder (cross-section), (d) virtual structure in height of $88 \mathrm{~mm}$ from the base of the cylinder (cross-section). The CET zone does not occur due to the lack of forced heat flux. The samples were etched: $5 \mathrm{~mL} \mathrm{HF}+20 \mathrm{~mL} \mathrm{HCl}+$ $20 \mathrm{~mL} \mathrm{HNO}_{3}+55 \mathrm{~mL}$ of $\mathrm{H}_{2} \mathrm{O}$. Parameters used for the simulation: $\lambda_{\mathrm{Q}}=0.5 \mathrm{~W} /(\mathrm{mK}), \alpha_{\mathrm{odl}-\mathrm{m}}=10,000 \mathrm{~W} /\left(\mathrm{m}^{2} \mathrm{~K}\right), \Delta \mathrm{T}_{\mathrm{m}-\mathrm{s}}=5 \mathrm{~K}$, $\mathrm{n}_{\mathrm{v}}=1 \times 10^{7} \mathrm{~m}^{-2}, \mathrm{n}_{\mathrm{s}}=1 \times 10^{5} \mathrm{~m}^{-2}, \Delta \mathrm{T}_{\mathrm{m}-\mathrm{v}}=2 \mathrm{~K}, \mathrm{a}_{3}=1.49 \times 10^{-7} \mathrm{~m} \mathrm{~s}^{-1} \mathrm{~K}^{-3}$.

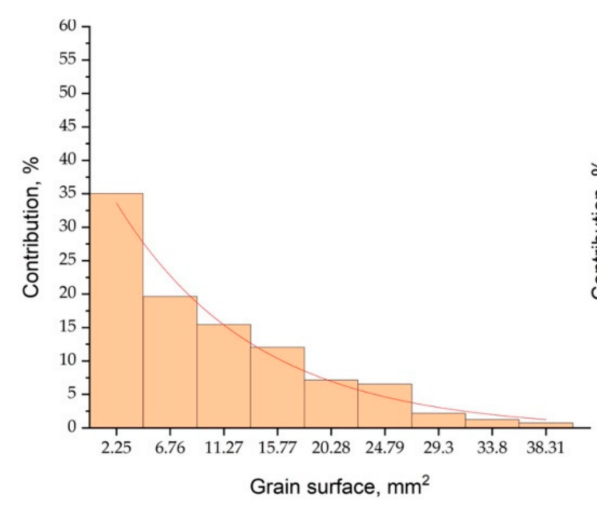

(a)

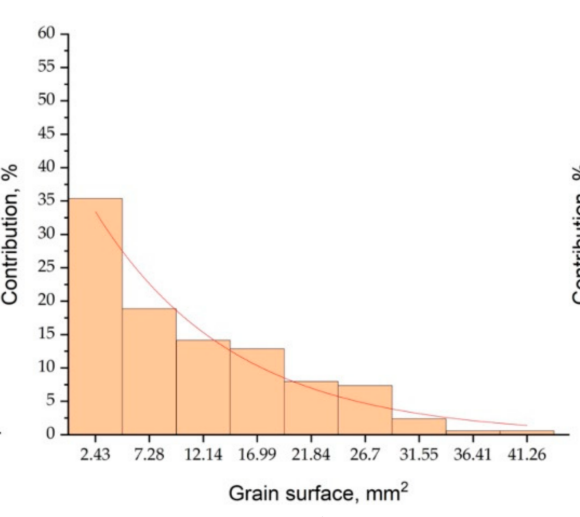

(b)

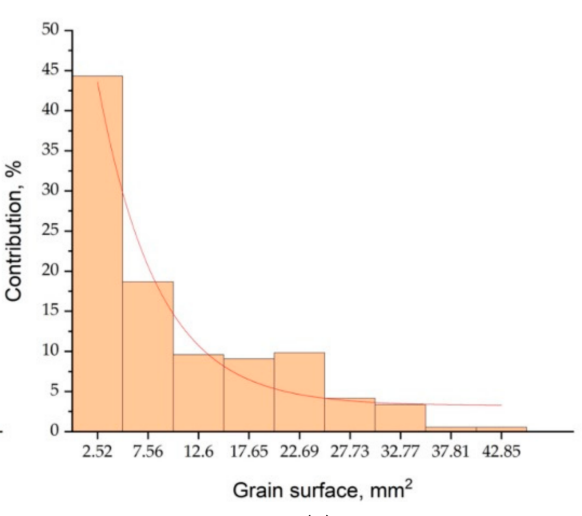

(c)

Figure 8. Surface histograms according to division into classes of pseudo-grains of the virtual structure (Figure 7) on the cross-section at distances from the base of the cylinder: (a) $44 \mathrm{~mm}$, (b) $88 \mathrm{~mm}$, (c) $116 \mathrm{~mm}$. 


\subsection{Validation of the CAFE-3D Model on the Basis of the Casting Solidifying in the Q-Ch Mould}

Validation studies of the model with regard to the structure (in macro terms) of the casting solidifying in the mould marked Q-Ch were carried out using the parameter values in the ranges given in Table 2 for the simulation. These values were selected successively based on the CET value analysis of virtual structures obtained from subsequent simulations. The virtual structure best fitted to the real structure is shown in Figure 9.

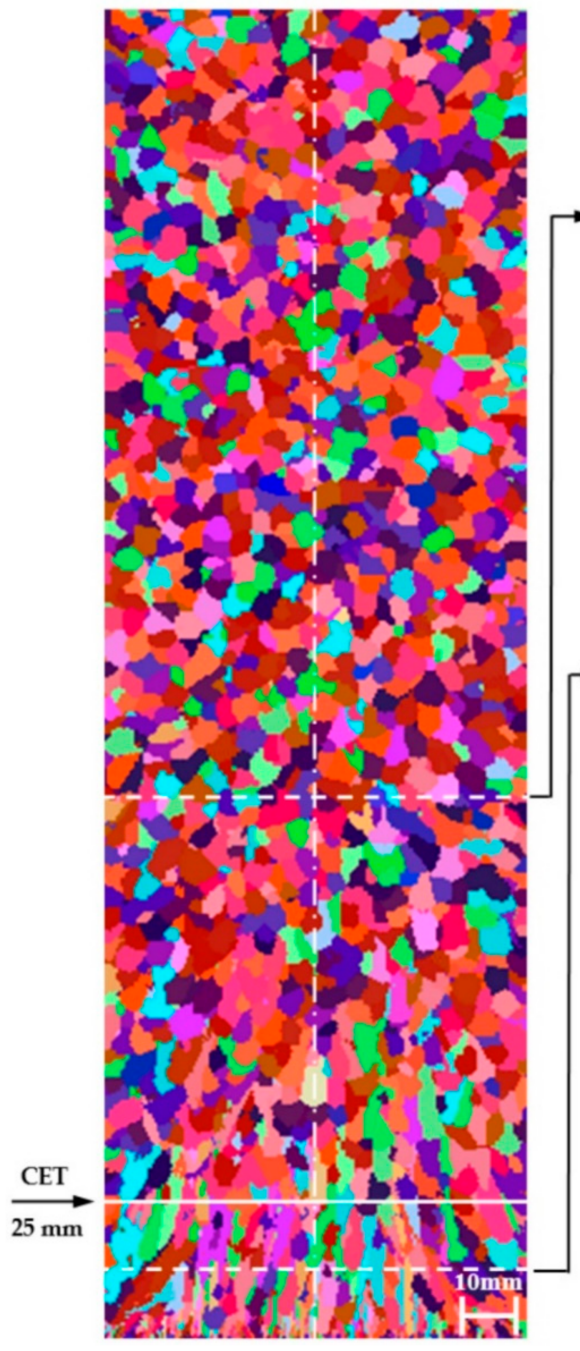

(a)

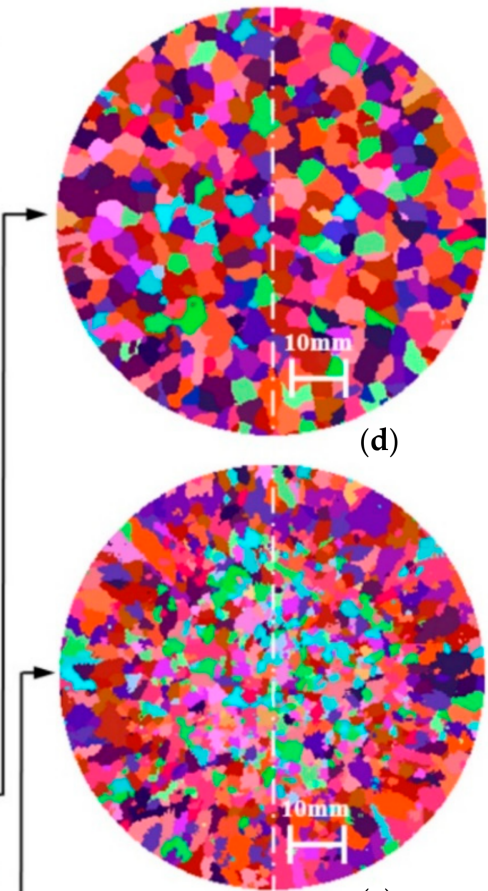

(c)

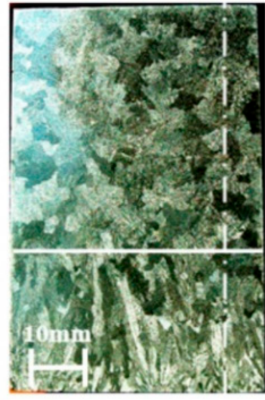

(b)

Figure 9. Setting of structures for casting solidifying in a uniform mould made of sand mass with a chill (Q-Ch): (a) virtual structure (longitudinal section), (b) real structure (longitudinal section), (c) virtual structure in height of $10 \mathrm{~mm}$ from the base of the cylinder (transverse cross-section), (d) virtual structure in height of $88 \mathrm{~mm}$ from the base of the cylinder (transverse cross-section). The samples were etched with $5 \mathrm{~mL} \mathrm{HF}+20 \mathrm{~mL} \mathrm{HCl}+20 \mathrm{~mL} \mathrm{HNO}_{3}+55 \mathrm{~mL}$ of $\mathrm{H}_{2} \mathrm{O}$. Parameters used for the simulation: $\lambda_{\mathrm{Q}}=1.0 \mathrm{~W} /(\mathrm{mK}), \alpha_{\text {odl-m }}=10,000 \mathrm{~W} /\left(\mathrm{m}^{2} \mathrm{~K}\right), \alpha_{\text {odl- } \mathrm{Q}}=4000 \mathrm{~W} /\left(\mathrm{m}^{2} \mathrm{~K}\right), \Delta \mathrm{T}_{\mathrm{m}-\mathrm{s}}=5 \mathrm{~K}, \mathrm{n}_{\mathrm{s}}=1 \times 10^{6} \mathrm{~m}^{-2}$, $\Delta \mathrm{T}_{\mathrm{m}-\mathrm{s}-\mathrm{Ch}-\mathrm{Q}}=15 \mathrm{~K}, \mathrm{n}_{\mathrm{s}-\mathrm{Ch}}=5 \times 10^{6} \mathrm{~m}^{-2}, \Delta \mathrm{T}_{\mathrm{m}-\mathrm{v}}=2 \mathrm{~K}, \mathrm{n}_{\mathrm{v}}=2 \times 10^{7} \mathrm{~m}^{-2}, \mathrm{a}_{3}=2 \times 10^{-10} \mathrm{~m} \mathrm{~s}^{-1} \mathrm{~K}^{-3}$.

The specification made on the basis of the grain surface distribution (Table 4 and Figure 10) of the average size of the columnar crystals on the cross-section $(\mathrm{z}=10 \mathrm{~mm})$ and equiaxed $(\mathrm{z}=88 \mathrm{~mm})$ of the virtual structure equal $\mathrm{d}_{\mathrm{av}}=2.91 \mathrm{~mm}$ and $4.28 \mathrm{~mm}$ shows a very good match to the real areas of the etched structure, amounting to $d_{\mathrm{av}}=2.95 \mathrm{~mm}$ and $4.31 \mathrm{~mm}$, respectively. 
Table 4. The values of the structure parameters (see Figure 9) Q-Ch variant.

\begin{tabular}{|c|c|c|c|c|c|}
\hline \multirow{3}{*}{ Structure Parameters-CAFE } & \multicolumn{3}{|c|}{ Virtual Structure } & \multicolumn{2}{|c|}{ Exp. Structure } \\
\hline & $\begin{array}{l}\mathrm{Z}=10 \mathrm{~mm} \\
\text { Crosswise }\end{array}$ & $\begin{array}{l}\mathrm{Z}=44 \mathrm{~mm} \\
\text { Crosswise }\end{array}$ & $\begin{array}{l}\mathrm{Z}=88 \mathrm{~mm} \\
\text { Crosswise }\end{array}$ & $\begin{array}{l}\mathrm{Z}=10 \mathrm{~mm} \\
\text { Crosswise }\end{array}$ & $\begin{array}{l}\mathrm{Z}=88 \mathrm{~mm} \\
\text { Crosswise }\end{array}$ \\
\hline & Columnar & \multicolumn{2}{|c|}{ Equiaxed } & Columnar & Equiaxed \\
\hline Total grain number $(\mathrm{Nb})$ & 1291 & 681 & 558 & 1221 & 512 \\
\hline Grains density on mould surface, $1 / \mathrm{m}^{2}$ & 335564 & 177009 & 145038 & 315963 & 133120 \\
\hline Average grain size $\mathrm{d}_{\mathrm{av}}, \mathrm{mm}$ & 2.91 & 3.75 & 4.28 & 2.95 & 4.31 \\
\hline
\end{tabular}

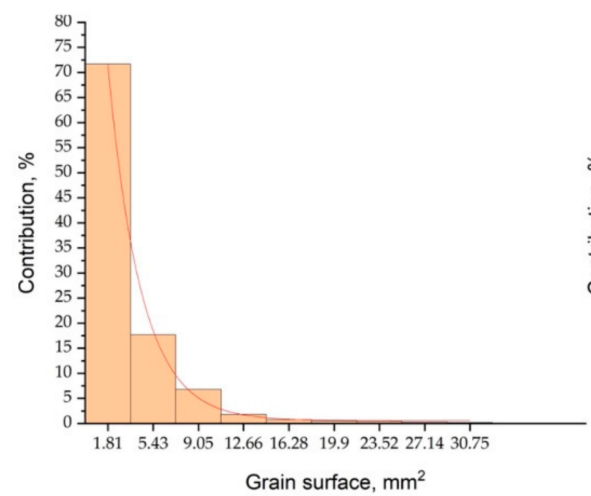

(a)

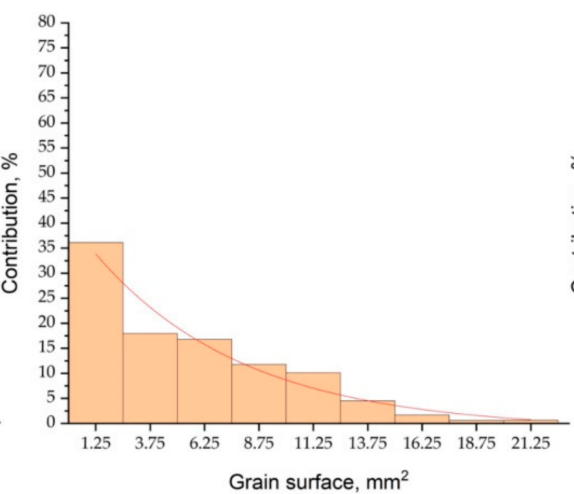

(b)

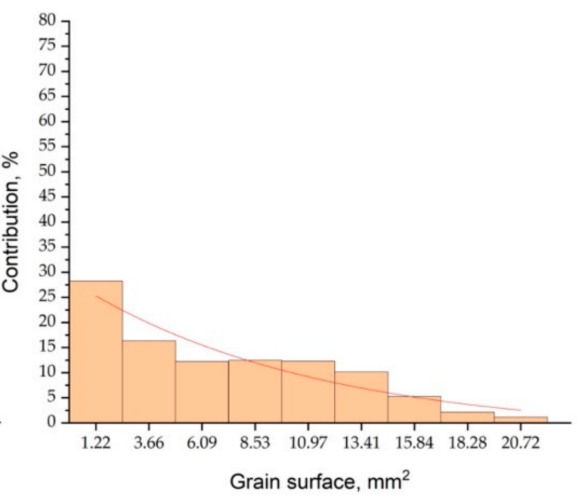

(c)

Figure 10. Surface histograms according to division into classes of pseudo-grains of the virtual structure (Figure 9) on the transverse cross-section at distances from the base of the cylinder: (a) $10 \mathrm{~mm}$, (b) $44 \mathrm{~mm}$, (c) $88 \mathrm{~mm}$.

The virtual structure on the longitudinal section shown in Figure 9a correctly predicts the extent of the CET zone $(27 \mathrm{~mm})$, the angle of their inclination in relation to the vertical axis of the casting (in the lower, central zone of the casting - the direction of heat flux preferred by the presence of a chill). In a virtual structure, in the lower central part of the casting with a radius of approx. $17 \mathrm{~mm}$, the $\gamma$ angle is $4-14^{\circ}$, and in the outer layer above the radius of 17 (up to $35 \mathrm{~mm}$ ) the $\gamma$ angle is $7-42^{\circ}$, respectively. Accordingly, the real structure (in the central part of the casting with a radius of approx. $17 \mathrm{~mm}$ is characterized by the $\gamma$ angle of $2-25^{\circ}$, and in the layer above the radius of 17 (up to $35 \mathrm{~mm}$ ), the $\gamma$ angle is $4-33^{\circ}$. The virtual structure in height of $\mathrm{z}=10 \mathrm{~mm}$ from the casting base contains a large number of columnar crystals, i.e., 1291 and this number is well approximated to the experimental one of 1221 (a difference of approx. 5.4\%).

The reduction of the $\gamma$ angle of inclination of the columnar crystals in relation to the vertical axis of the casting, taking into account the degree of their mutual orientation, should be carried out by influencing the virtual structure by increasing the value of $\alpha_{\text {cast-Ch }}$ over $3000 \mathrm{~W} / \mathrm{m}^{2} \mathrm{~K}$ and decreasing the value of $\mathrm{a}_{3}$ under $5 \times 10^{-10} \mathrm{~m} \mathrm{~s}^{-1} \mathrm{~K}^{-3}$. Increasing the value of $\alpha_{\text {cast-Ch }}$ always increases the CET value. The reduction of the CET value can be done by increasing the number of grains in the bulk of the liquid phase $\mathrm{n}_{\mathrm{v}}$.

\subsection{Validation of the CAFE-3D Model on the Basis of the Casting Solidifying in the HI-Ch Mould}

Validation studies of the model of creating the casting structure solidifying in the $\mathrm{HI}-\mathrm{Ch}$ mould were carried out on the basis of the analysis of the parameter values adopted for simulation in the ranges given in Table 2 . These values were selected successively based on the CET value analysis of virtual structures obtained from subsequent simulations. The virtual structure best fitted to the real structure is shown in Figure 11, the values of the virtual and experimental structure parameters are presented in Table 5. 


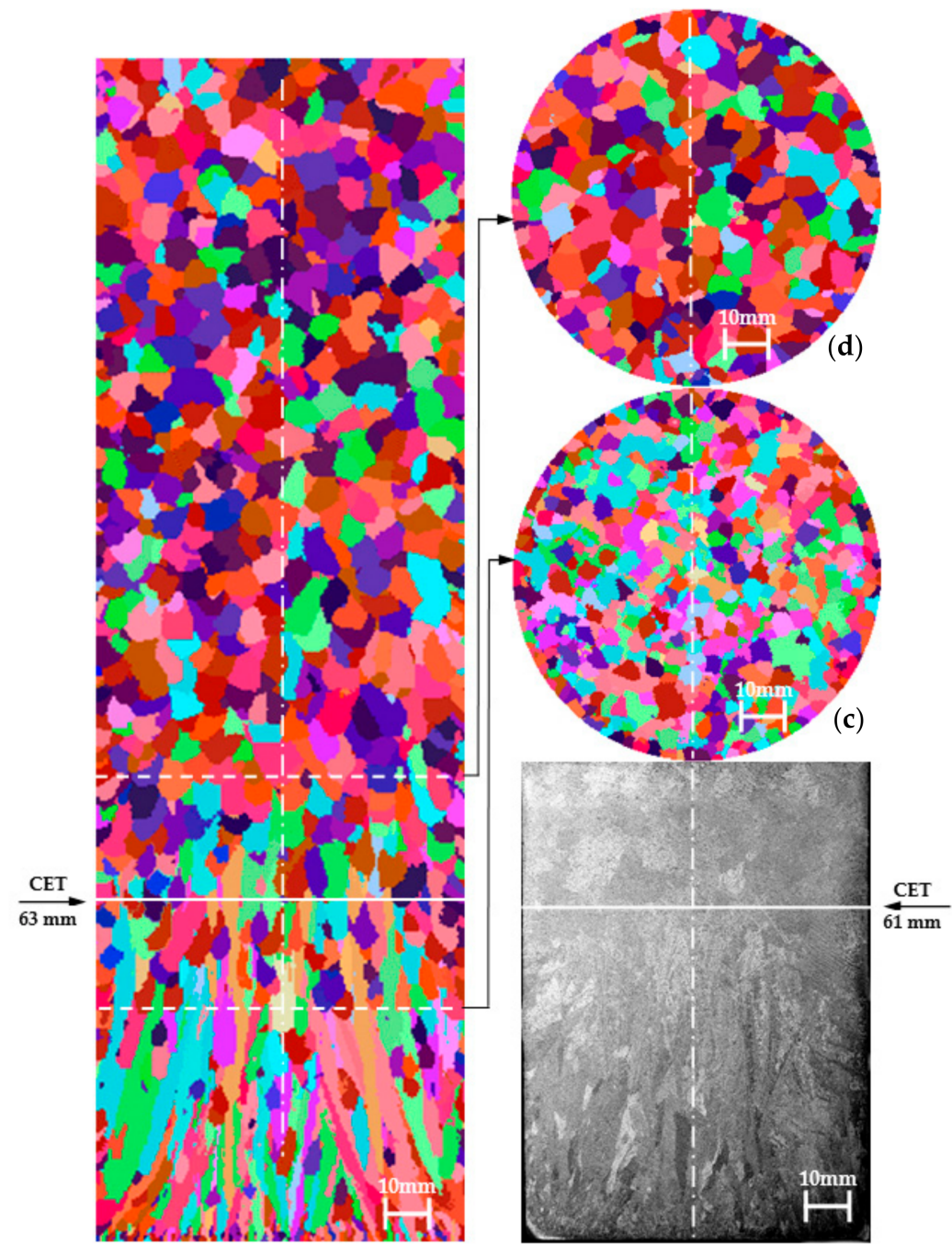

(a)

(b)

Figure 11. Setting of structures for casting solidifying in a uniform mould made of insulating mass with a chill (HI-Ch): (a) virtual structure (longitudinal section), (b) real structure (longitudinal section), (c) virtual structure in height of $44 \mathrm{~mm}$ from the base of the cylinder (transverse cross-section), (d) virtual structure in height of $88 \mathrm{~mm}$ from the base of the cylinder (transverse cross-section). The samples were etched: $5 \mathrm{~mL} \mathrm{HF}+20 \mathrm{~mL} \mathrm{HCl}+20 \mathrm{~mL} \mathrm{HNO}_{3}+55 \mathrm{~mL}$ of $\mathrm{H}_{2} \mathrm{O}$. Parameters used for the simulation: $\lambda_{\mathrm{HI}}=0.5 \mathrm{~W} /(\mathrm{mK}), \alpha_{\text {odl-m }}=10,000 \mathrm{~W} /\left(\mathrm{m}^{2} \mathrm{~K}\right), \alpha_{\text {odl-Ch}}=2500 \mathrm{~W} /\left(\mathrm{m}^{2} \mathrm{~K}\right), \Delta \mathrm{T}_{\mathrm{m}-\mathrm{s}}=5 \mathrm{~K}$, $\mathrm{n}_{\mathrm{v}}=8 \times 10^{6} \mathrm{~m}^{-2}, \mathrm{n}_{\mathrm{s}}=1 \times 10^{6} \mathrm{~m}^{-2}, \Delta \mathrm{T}_{\mathrm{m}-\mathrm{v}}=2 \mathrm{~K}, \mathrm{a}_{3}=5 \times 10^{-9} \mathrm{~m} \mathrm{~s}^{-1} \mathrm{~K}^{-3}$.

Table 5. The values of the structure parameters (Figure 11).

\begin{tabular}{|c|c|c|c|c|c|}
\hline \multirow[b]{3}{*}{ Structure Parameters-CAFE } & \multicolumn{4}{|c|}{ Virtual Structure } & \multirow{2}{*}{$\begin{array}{c}\text { Exp. Structure } \\
\mathrm{Z}=44 \mathrm{~mm}\end{array}$} \\
\hline & $\mathrm{Z}=44 \mathrm{~mm}$ & $\mathrm{Z}=88 \mathrm{~mm}$ & $\mathrm{Z}=\mathbf{1 1 6} \mathrm{m}$ & $Y=0 \mathrm{~mm}$ & \\
\hline & Columnar & \multicolumn{2}{|c|}{ Equiaxed } & & columnar \\
\hline Total grain number $(\mathrm{Nb})$ & 689 & 444 & 393 & 1417 & 658 \\
\hline Grains density on mould surface, $1 / \mathrm{m}^{2}$ & 179088 & 114076 & 102150 & 92012 & 171013 \\
\hline Average grain size $\mathrm{d}_{\mathrm{av}}, \mathrm{mm}$ & 4.06 & 4.64 & 5.09 & 5.06 & 4.1 \\
\hline
\end{tabular}

The obtained virtual structures and their values: CET (Figure 11), size $\mathrm{d}_{\mathrm{av}}$ (Table 5) indicate that parameters with values $\mathrm{n}_{\mathrm{v}} \leq 1 \times 10^{7} \mathrm{~m}^{-3}$ and $\mathrm{a}_{3} \leq 1 \times 10^{-8} \mathrm{~m} \cdot \mathrm{s}^{-1} \cdot \mathrm{K}^{-3}$ enable us to obtain a satisfactory approximation of the CET and $\mathrm{d}_{\mathrm{av}}$ of the real structure, visible on the etched sample. The average size of equiaxed crystals on the transverse 
cross-section $(\mathrm{z}=10 \mathrm{~mm})$ of the virtual structure $\left(\mathrm{d}_{\mathrm{av}}=2.9 \mathrm{~mm}\right)$ is very well matched to the real areas of the etched structure $\left(\mathrm{d}_{\mathrm{av}}=3.0 \mathrm{~mm}\right)$. The virtual structure at height of $\mathrm{z}=44 \mathrm{~mm}$ from the casting base contains 689 columnar crystals and this number is well approximated to the experimental one of 658 (difference of approx. $4.5 \%$ ). The greatest distance of the CET zone of the virtual structure is approx. $63 \mathrm{~mm}$, while in the real casting it is approx. $61 \mathrm{~mm}$ (central part of the casting). The angle of inclination of the bar crystals measured in regard to the vertical axis of the casting at a distance (radius) of $15 \mathrm{~mm}$ from the axis, i.e., the central part of the casting, is $0-10^{\circ}$ for both the experimental and virtual structure. However, in the remaining area for the experimental structure, the angle $\gamma$ is $16-48^{\circ}$ with respect to the virtual structure, where $\gamma$ is $12-45^{\circ}$. The greatest inclination angles of the crystals are observed from the side of contact with the chill at the edge of the casting. Therefore, also a good approximation of the virtual structure to the real one was obtained due to the angle of the crystals.

The analysis of the test results shows that a relatively good approximation of the virtual and real structure of the casting solidifying in the HI-Ch mould can be obtained by using the following parameter values for the CAFE-3D model:

- $\quad$ parameters assumed to be of constant value: $\alpha_{\text {cast-m }}=10,000 \mathrm{~W} /\left(\mathrm{m}^{2} \mathrm{~K}\right), \Delta \mathrm{T}_{\mathrm{m}-\mathrm{s}}=5 \mathrm{~K}$, $\Delta \mathrm{T}_{\mathrm{m}-\mathrm{s}-\mathrm{Ch}-\mathrm{HI}}=10 \mathrm{~K}, \Delta \mathrm{T}_{\mathrm{m}-\mathrm{v}}=2 \mathrm{~K}, \sigma_{\Delta \mathrm{Ts}-\mathrm{HI}}=0.4 \mathrm{~K}, \sigma_{\Delta \mathrm{Ts}-\mathrm{Ch}}=0.4 \mathrm{~K}, \sigma_{\Delta \mathrm{Tv}}=0.4 \mathrm{~K}$,

- parameters with values assumed to be variable in the range: $\lambda_{\mathrm{Q}}=0.3-0.5 \mathrm{~W} /(\mathrm{m} \mathrm{K})$, $\alpha_{\text {cast-Ch }}=1500-2500 \mathrm{~W} / \mathrm{m}^{2} \mathrm{~K}, \mathrm{n}_{\mathrm{s}}=(1-5) 10^{5} \mathrm{~m}^{-2}, \mathrm{n}_{\mathrm{s}-\mathrm{Ch}}=(8-10) 10^{5} \mathrm{~m}^{-2}, \mathrm{n}_{\mathrm{v}}=(8-10) 10^{6}$ $\mathrm{m}^{-3}, \mathrm{a}_{3}=(1-3) 10^{-9} \mathrm{~m} \mathrm{~s}^{-1} \mathrm{~K}^{-3}$.

The reduction of the $\gamma$ angle of the inclination of the columnar pseudo-dendrites and their degree of mutual orientation should be adjusted by increasing the value of $\alpha_{\text {cast-Ch }}$ over $2500 \mathrm{~W} / \mathrm{m}^{2} \mathrm{~K}$ and decreasing the value of $\mathrm{a}_{3}$ under $3 \times 10^{-9} \mathrm{~m} \mathrm{~s}^{-1} \mathrm{~K}^{-3}$.

\subsection{Example of Predicting Microstructure under Conditions of Extreme Heat Transfer}

Moreover, an attempt was made to predict the microstructure resulting from the application of a diode laser, the beam of which influences the surface of the AlSi7Mg alloy sample made in the die-casting mould (Figure 12). This method is used to improve the tribological properties by significantly crumbling the grain in the surface layer and alloying it [54-57]. The laser heat treatment process was carried out using a TRUMPF TruDiode 3006 diode laser (TRUMPF, Ditzingen, Germany) with a maximum power of $3 \mathrm{~kW}$. To manipulate the location of the laser beam a KR16-2 robot (KUKA, Augsburg, Germany) was used. Beam diameter $\mathrm{d}=2.18 \mathrm{~mm}$, power $1800 \mathrm{~W}$, velocity $5.5 \mathrm{~m} / \mathrm{s}$, energy per surface $150.1 \mathrm{~J} / \mathrm{mm}^{2}$.

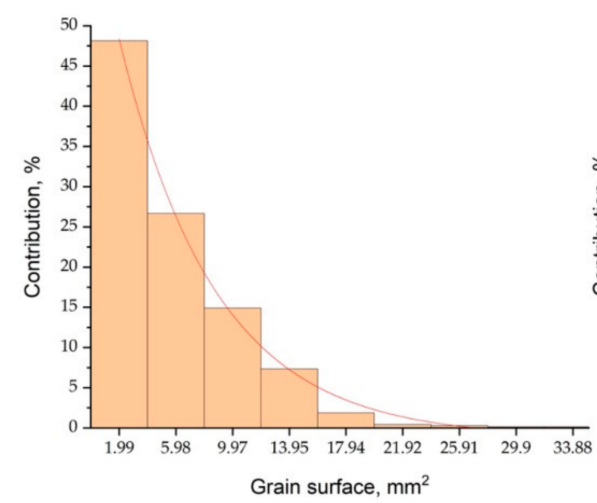

(a)

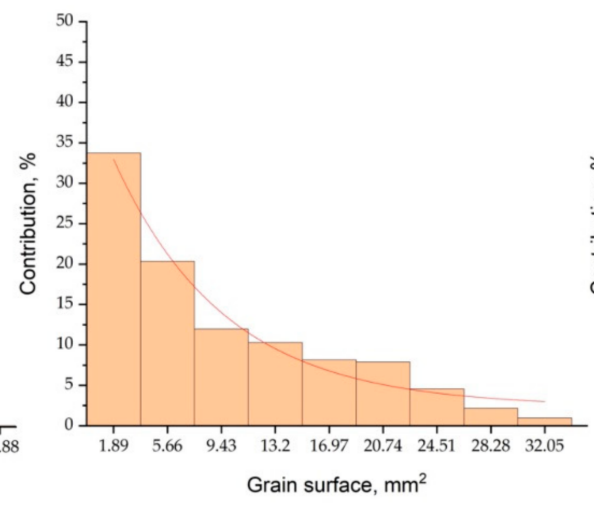

(b)

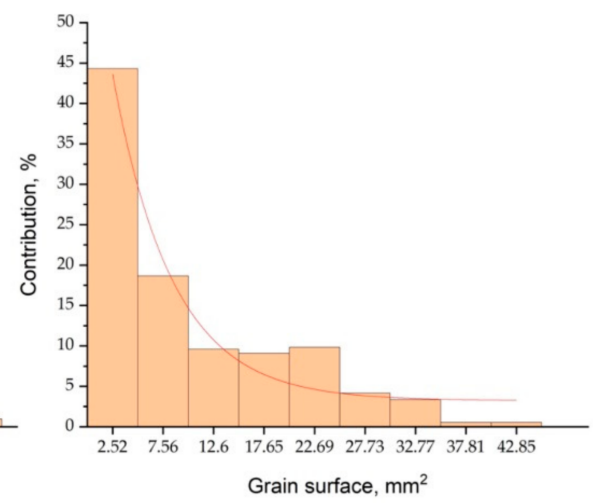

(c)

Figure 12. Surface histograms according to division into classes of pseudo-grains of the virtual structure (Figure 11) on the transverse cross-section at the distances Z: (a) $44 \mathrm{~mm}$, (b) $88 \mathrm{~mm}$, (c) $116 \mathrm{~mm}$.

In these tests, the Calcosoft-CAFE simulation code was used, which is the prototype of the $3 \mathrm{D}$ version. An important problem encountered in this process was the method of 
determining the values of the parameters (the thermal model and the model responsible for structure prediction) under extreme heat extraction conditions during laser remelting of the casting surface and its subsequent rapid crystallization. Due to the very high heating/cooling rates and a relatively small remelting area, it was necessary to use a very small FEM mesh size of $0.02 \mathrm{~mm}$ (in the conditions of classic casting $1 \mathrm{~mm}$ and more) and a cellular automaton grid from 1 to $5 \mu \mathrm{m}$ (in the conditions of classic casting $100 \mu \mathrm{m}$ ) and to drastically reduce the time step to $1 \times 10^{-8} \mathrm{~s}$ (the case with a copper chill is approx. from 0.5 to $1 \mathrm{~s})$.

Moreover, it was necessary in the database defined for the CAFE module to significantly increase the value of the heat transfer coefficient (melted drop-non-melted material system) up to the value of $1 \times 10^{8} \mathrm{~W} / \mathrm{m}^{2} \mathrm{~K}$ (cast-chill from 2500 to $4000 \mathrm{~W} / \mathrm{m}^{2} \mathrm{~K}$ ). Whereas, the value of the empirical coefficient entering the correlation on nuclei density at the interface liquid phase-non-melted material should be assumed as $n_{\text {casting-mould }}=1 \times 11 \mathrm{~m}^{-2}$ (case with chill $\mathrm{n}_{\text {casting-mould }}=1 \times 10^{5} \mathrm{~m}^{-2}$ ).

The simulation results were consistent with the experiment. In Figure 13a, the actual structure is shown with a visible non-melted material and melted zone. There is no visible transition zone from columnar to equiaxed (CET) crystals between the two zones as was in the case of the variants described in the previous section. In places bordering with the non-melted zone, the formation and growth of fragmented columnar crystals can be observed without a gradual reduction of the structure grains. Columnar crystals are formed in the non-melted material structure as a result of the forced large heat flux by removing the heat of the casted zone through the non-melted zone. On the virtual structure (Figure 13b), the formation and growth direction of columnar crystals formed at the interface with the non-melted material zone can be observed, due to the forced large temperature gradient from the contact zone with the non-melted zone, spreading towards the contact of the melted layer with the ambient. Both in the real and virtual structure, the formation of equiaxed crystals was not observed, due to specific thermal conditions, i.e., forced large heat flux.

\section{$3.9 \mathrm{~mm}$}

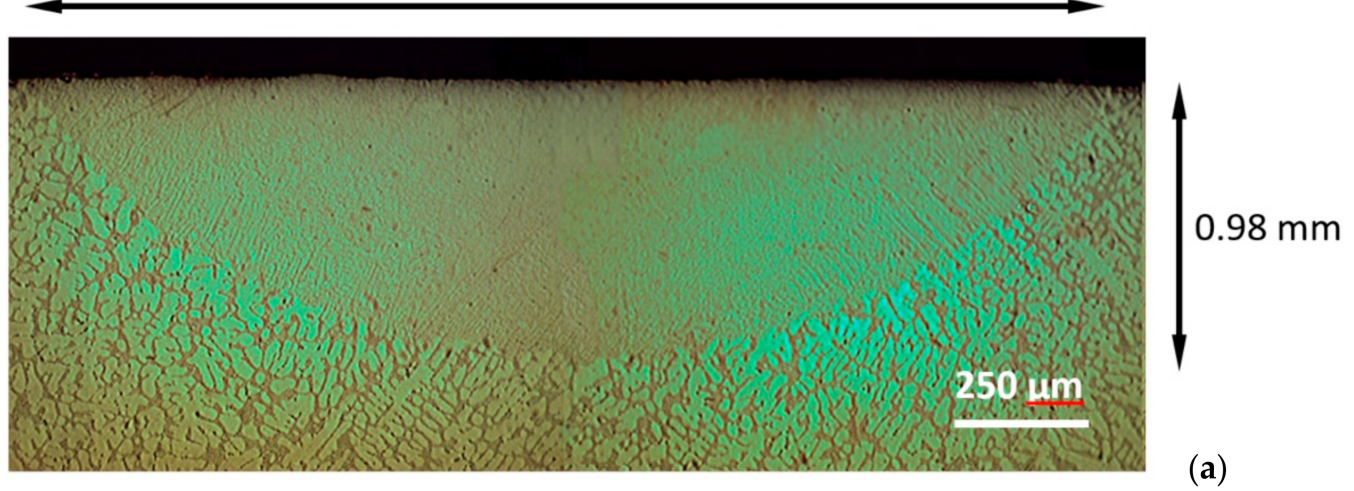

$3.95 \mathrm{~mm}$

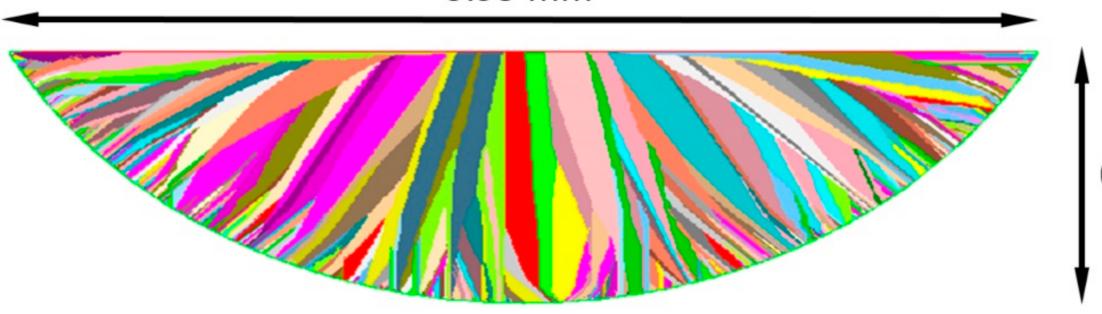

$0.9 \mathrm{~mm}$

Figure 13. Result of experimental and simulation validation in the Calcosoft CAFE 2D code: (a) real microstructure (Nikon ECLIPSE MA200 microscope), (b) virtual microstructure. 
In the next stage, microscopic examination (ECLIPSE MA200 microscope, Nikon, Tokyo, Japan) of the microstructure refinement was performed. The parameter determining the refinement of the structure is the dendrite arm spacing (DAS). This parameter was obtained on the basis of arithmetic average measurements of dendrite arm distances in the non-melted material and melted zones. Therefore, in the non-melted zone, the average values were $41 \mu \mathrm{m}$, while in the melted zone $4.5 \mu \mathrm{m}$. Consequently, the refinement of the solid $\alpha$ solution was performed nine times.

The same sample was subjected to microscopic examination using a microhardness tester to determine the Vickers micro-hardness (VMH 002VD microscope type microharness tester, Walter UHL Technische, Aßlar, Germany). The applied force was HV 0.025 of $0.2452 \mathrm{~N}$. The test was performed in accordance with EN ISO 6507-1:2005. A Vickers microhardness of 60-71 HV 0.025 ( 66 HV 0.025 on average) was obtained in the non-melted zone. In the melted zone, the microhardness significantly improved and ranged from $85-92$ HV 0.025 ( 88 HV 0.025 on average). Therefore, the refinement of the structure caused by the high cooling rates increased the relative difference between the microhardness obtained in the melted and non-melted zone by $25 \%$. This has an obvious effect on the improvement of the tribological properties.

\section{Discussion}

A collective summary of the test results related to the validation of the Calcosoft CAFE $3 \mathrm{D}$ model is presented in Table 5 . The Calcosoft database is very poor, and additionally the publications of the system creators do not provide a wide range of parameter values. Therefore, first of all it was necessary to test the sensitivity of the CAFE model to variations in the values of individual parameters, and then to adjust the selected cases of the virtual structure to the real one (Q-Q, Q-Ch, HI-Ch), which enabled the determination of their reasonable (real) limits of applicability (application). It is therefore a very extensive attempt to expand the database of the above-mentioned simulation system. Table 6 shows the adopted ranges of the CAFE model parameter values, indicating the values of the parameters for which the best matching of virtual structures to the real ones was obtained for individual material configurations of moulds, taking into account the location of the CET zone, as well as the average grain size- $\mathrm{d}_{\mathrm{av}}$. The recommended specified ranges of variations of the values of the CAFE model parameters for the comparative analysis of the deviation angle from the direction forced by the chill influence of directed pseudo-crystallites of the virtual structure and dendrites of the real structure are also given.

The analysis of the results of the validation tests shows that in the prediction of the structure using the Calcosoft CAFE-3D model of the solidifying casting in the thermal conditions of the mould (Q-Q, Q-Ch, HI-Ch) assumed in the operation, it results that the influence of individual parameters used in these coupled models the simulation result is varied. This impact was estimated using the notation in Table 5-! for little impact, !!-for medium and !!! for high one. This applies to both groups of parameters, i.e., those occurring in the thermal model and the model related to the phenomena of nucleation and structure growth. If there is a need to correct the match of the virtual structure to the real one, it should be made by adjusting the value of the nuclei density parameter in the bulk of casting $-\mathrm{n}_{\mathrm{V}}$, and when the length of the CET zone is reduced too low, then it should be increased, first of all by increasing the kinetic coefficient $-\mathrm{a}_{3}$ and then by increasing the value of the heat transfer coefficient at the cast-chill interface- $-\alpha_{\text {cast-Ch }}$. 
Table 6. Summary of validation results for the casting with greater massiveness in all three moulds: Q-Q, Q-Ch and HI-Ch

\begin{tabular}{|c|c|c|c|c|c|c|c|c|c|c|}
\hline 焉 & Parameter & $\begin{array}{l}\text { Symbol } \\
\text { and } \\
\text { Unit }\end{array}$ & \multicolumn{3}{|c|}{$\begin{array}{l}\text { Value or Range of the Tested Values of the } \\
\text { Model Parameters } \\
\text { and Influence in the Model } \\
\text { (High-!!!, Middle-!!, Low-!) }\end{array}$} & \multicolumn{3}{|c|}{$\begin{array}{l}\text { Parameter Values for the Best Fit of } \\
\text { the Model for CET and } d_{a v}\end{array}$} & \multicolumn{2}{|c|}{$\begin{array}{l}\text { Recommended Ranges of Parameter } \\
\text { Value Changes when Varianting the } \\
\text { Position Pseudocrystals Angle }(\gamma) \text { while } \\
\text { Maintaining the CET Value }\end{array}$} \\
\hline \multirow{2}{*}{ 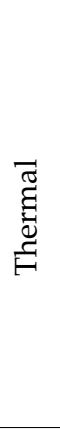 } & $\begin{array}{l}\text { Heat } \\
\text { conduction of } \\
\text { the mould }\end{array}$ & $\begin{array}{c}\lambda_{\mathrm{Q} / \mathrm{HI}} \\
\mathrm{W} /(\mathrm{mK})\end{array}$ & $\begin{array}{c}0.5-2 \\
(!)\end{array}$ & $\begin{array}{l}0.5-1.5 \\
(!)\end{array}$ & $\begin{array}{l}0.2-1.5 \\
(! !)\end{array}$ & 0.5 & 1.0 & 0.5 & $0.75-1$ & $0.3-0.5$ \\
\hline & $\begin{array}{c}\text { HTC } \\
\text { casting-chill }\end{array}$ & $\begin{array}{c}\alpha_{\text {cast-Ch }} \\
\mathrm{W} /\left(\mathrm{m}^{2} \mathrm{~K}\right)\end{array}$ & - & $\begin{array}{l}100-4000 \\
(! !)\end{array}$ & $\begin{array}{l}50-5000 \\
\quad(! !)\end{array}$ & - & 4000 & 2500 & $\begin{array}{c}3000 \\
- \\
4000\end{array}$ & $\begin{array}{c}1500 \\
- \\
2500\end{array}$ \\
\hline \multirow{4}{*}{ 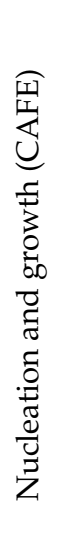 } & $\begin{array}{l}\text { Undercooling } \\
\text { at mould } \\
\text { surface }\end{array}$ & $\frac{\Delta \mathrm{T}_{\mathrm{m}-\mathrm{s}}}{\mathrm{K}}$ & $\begin{array}{c}2-5 \\
(!)\end{array}$ & $\begin{array}{c}5 \\
(!)\end{array}$ & $\begin{array}{l}2.5-10 \\
(!)\end{array}$ & 5 & 5 & 5 & 5 & 5 \\
\hline & $\begin{array}{c}\text { Nuclei } \\
\text { Number at } \\
\text { mould surface }\end{array}$ & $\begin{array}{c}\mathrm{n}_{\mathrm{s}} \\
1 / \mathrm{m}^{2}\end{array}$ & $\begin{array}{c}1 \times 10^{4} \\
- \\
1 \times 10^{8} \\
(! !)\end{array}$ & $\begin{array}{c}1 \times 10^{3} \\
- \\
1 \times 10^{7} \\
(! !)\end{array}$ & $\begin{array}{c}1 \times 10^{5} \\
- \\
1 \times 10^{8} \\
(! !)\end{array}$ & $1 \times 10^{5}$ & $1 \times 10^{5}$ & $1 \times 10^{5}$ & $(1-5) 10^{5}$ & $(1-5) \mathrm{e} 5$ \\
\hline & $\begin{array}{l}\text { Undercooling } \\
\text { at chill surface }\end{array}$ & $\underset{\mathrm{K}}{\Delta \mathrm{T}_{\mathrm{m}-\mathrm{s}-\mathrm{Ch}-\mathrm{Q} / \mathrm{HI}}}$ & - & $\begin{array}{c}10-15 \\
(!)\end{array}$ & $\begin{array}{c}5-20 \\
(!) \\
\end{array}$ & - & 15 & 10 & $10-15$ & $10-15$ \\
\hline & $\begin{array}{l}\text { Nuclei } \\
\text { number at } \\
\text { chill surface }\end{array}$ & $\begin{array}{l}\mathrm{n}_{\mathrm{s}-\mathrm{Ch}} \\
1 / \mathrm{m}^{2}\end{array}$ & - & $\begin{array}{l}5 \times 10^{5} \\
- \\
5 \times 10^{7} \\
\quad(!)\end{array}$ & $\begin{array}{c}1 \times 10^{5} \\
- \\
1 \times 10^{8} \\
(!)\end{array}$ & - & $5 \times 10^{6}$ & $8 \times 10^{5}$ & $(1 \div-5) 10^{7}$ & $(8-10) 10^{5}$ \\
\hline
\end{tabular}


Table 6. Cont

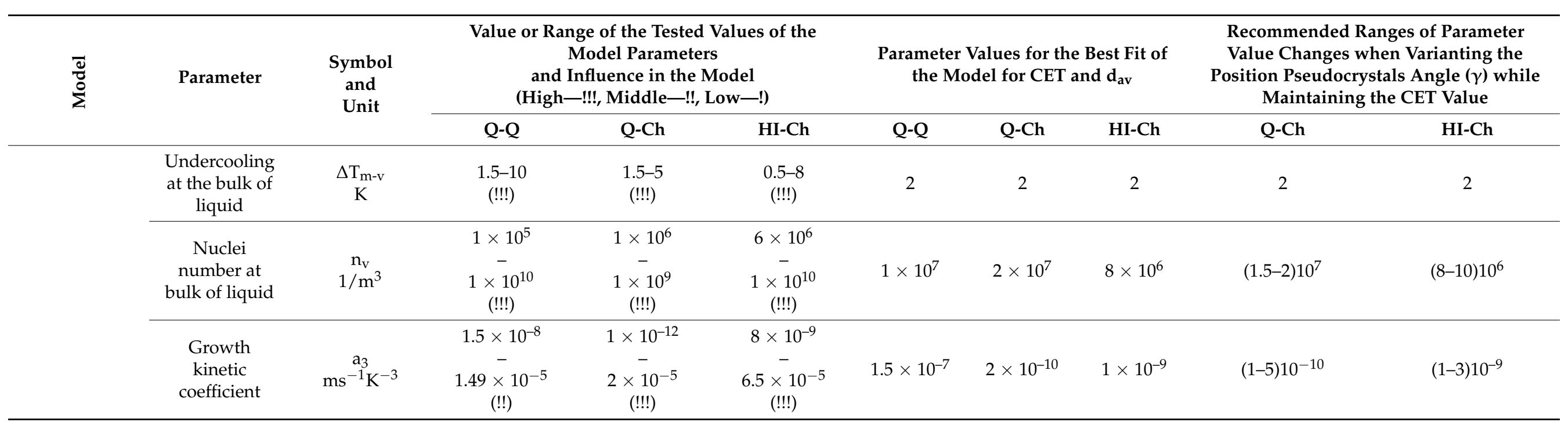


The reduction of the $\gamma$ angle of the columnar crystals in relation to the vertical axis of the casting (the direction of the main component of the flux preferred by the location of the chill), taking into account the degree of their mutual orientation, should be analysed by affecting the virtual structure by increasing the value of the heat transfer coefficient at the casting and chill interface $-\alpha_{\text {cast-Ch }}$ and by reducing the value of the kinetic coefficient- $a_{3}$.

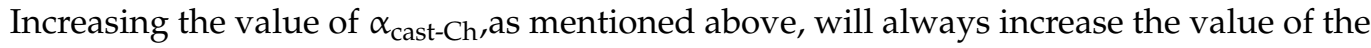
CET zone. Whereas, the reduction of the CET zone value in this case can be achieved by increasing the density of the grains in the bulk of the liquid phase $-n_{v}$. These activities specifying the validation of the structure formation model go beyond the area of two basic predicting parameters (virtual structure), which are the CET zone position value and the average grain size $d_{a v}$ (see Table 7 ). This requires a good orientation of the CAFE system user in the sensitivity issues of this coupled model, which is shown in Table 1.

Table 7. The tendency of the CAFE-3D model parameters influence.

\begin{tabular}{|c|c|c|c|c|c|c|}
\hline \multirow{2}{*}{$\begin{array}{l}\text { Mould } \\
\text { Type }\end{array}$} & \multirow{2}{*}{$\begin{array}{l}\text { Structure } \\
\text { Parameter }\end{array}$} & \multicolumn{5}{|c|}{ Model Parametr } \\
\hline & & $\lambda_{\text {mould }} \uparrow$ & $\alpha_{\text {cast-Ch }} \uparrow$ & $\Delta \mathrm{T}_{\mathbf{v}} \uparrow$ & $\mathbf{n}_{\mathbf{v}} \uparrow$ & $\mathbf{a}_{3} \uparrow$ \\
\hline \multirow{2}{*}{$\mathrm{Q}-\mathrm{Q}$} & $\mathrm{d}_{\mathrm{av}}$ & $\uparrow \downarrow$ & - & $\uparrow$ & $\downarrow$ & $\uparrow$ \\
\hline & CET & $\uparrow$ & - & $\uparrow$ & $\downarrow$ & $\uparrow$ \\
\hline \multirow{3}{*}{$\mathrm{Q}-\mathrm{Ch}$} & $\mathrm{d}_{\mathrm{av}}$ & $\uparrow$ & $\downarrow$ & $\uparrow$ & $\downarrow$ & $\uparrow$ \\
\hline & CET & $\downarrow$ & $\uparrow$ & $\uparrow$ & $\downarrow$ & $\uparrow$ \\
\hline & $\gamma$ & $\uparrow \downarrow$ & $\downarrow$ & - & - & $\downarrow$ \\
\hline \multirow{3}{*}{$\mathrm{HI}-\mathrm{Ch}$} & $\mathrm{d}_{\mathrm{av}}$ & $\uparrow \downarrow$ & $\downarrow$ & $\uparrow$ & $\downarrow$ & $\uparrow$ \\
\hline & CET & $\downarrow$ & $\uparrow$ & $\uparrow$ & $\downarrow$ & $\uparrow$ \\
\hline & $\gamma$ & $\uparrow \downarrow$ & $\downarrow$ & - & - & $\downarrow$ \\
\hline
\end{tabular}

\section{Conclusions}

The influence of individual parameters on the simulation result was determined. Therefore, the following conclusions will be of a general nature and will provide guidelines for further work.

The conducted analysis of the state of knowledge about the basics of crystallization of metals and alloys and their use to predict the structure in castings by means of coupled modelling, a review of the methods and simulation systems used, and most of all the experimental and simulation studies carried out on the CAFE system validation enable the following summary:

(1) From the phenomena accompanying the creation of a structure in a real casting, coupled in a way resulting from the nature of the process, the most important of them were selected, namely the heat flux in the cast-mould system (thermal conductivity of the moulding sand, heat transfer coefficient on the cast-mould and cast-chill interface) and nucleation and crystal growth phenomena (undercooling at the mould surface, number of nuclei at the mould surface, undercooling at the chill surface, number of nuclei at the chill surface, undercooling in the bulk of casting, number of grains in the bulk of casting, kinetic growth coefficient $\mathrm{a}_{3}$ ).

(2) The developed methodology and designed stands for conducting experimental and simulation validation studies met the assumptions of a modern, special and comprehensive validation procedure, going beyond the validation of thermal phenomena. It was shown that it was necessary to adequately "isolate" the mentioned modelled coupled phenomena in terms of interpretation.

(3) A set of model parameter values was developed for castings with a diameter of $\$ 70 \mathrm{~mm}$, which enabled the most accurate prediction of the AlSi7Mg alloy structure in the chill impact zone and outside its zone (in this dimensional area of castings cooled intensively from the bottom side). 
(4) Also, the algorithms were included that enable to predict the structure defined by the following parameters:

- degree of refinement (grain size- $\mathrm{d}_{\mathrm{av}}$ ) with the interpretation of the restriction $\mathrm{d}_{\mathrm{av}}$ to the hypoeutectic phase,

- location of the columnar-to-equiaxed transition zone-CET

- $\quad$ angle of the crystals in relation to the vertical axis of the casting- $\gamma$.

(5) The CAFE model requires a special approach in the selection of parameter values under conditions of intense heat transfer, such as the case of rapid remelting and rapid solidification of small volumes of the alloy. It is necessary to enrich the database of materials and the database of boundary conditions with appropriate values depending on the intensity of heat transfer. In order to better match the thermal conditions in such cases, and to better identify variations in temperature fields with time, it is worth using the IR thermography method [58].

(6) The above conclusion in some approximation (not so extreme) also applies to variants using chills in classic heat removal conditions.

(7) The next step in modelling the microstructure should be to achieve dendritic structures in three-dimensional modelling for entire castings. Moreover, it includes the occurrence of eutectics in the interdendritic spaces. As well as the transfer of the obtained structure parameters (distances between the arms of the dendrites-DAS, i.e., the degree of their refinement, the size of the eutectic particles) on the mechanical properties (tensile strength, accepted yield point, elongation, hardness). It is now necessary to develop new empirical models, which until now were mainly related to the cooling rate of the alloy.

Author Contributions: Conceptualization, J.H. and P.P.; methodology, J.H. and P.P.; validation, J.H.; formal analysis, J.H.; investigation, J.H., R.S., M.R., W.M. and S.L.; writing-review and editing, J.H.; visualization, J.H. and R.S. All authors have read and agreed to the published version of the manuscript.

Funding: This research was funded by the Polish Ministry of Science and Higher Education, grants number 0613/SBAD/4677.

Institutional Review Board Statement: Not applicable.

Informed Consent Statement: Not applicable.

Data Availability Statement: The data presented in this study are available on request from corresponding author.

Conflicts of Interest: The authors declare no conflict of interest.

\section{References}

1. Kurz, W.; Rappaz, M.; Trivedi, R. Progress in modelling solidification microstructures in metals and alloys. Part II: Dendrites from 2001 to 2018. Int. Mater. Rev. 2020, 1-47. [CrossRef]

2. Shibuta, Y.; Ohno, M.; Takaki, T. Solidification in a Supercomputer: From Crystal Nuclei to Dendrite Assemblages. JOM 2015, 67, 1793-1804. [CrossRef]

3. Sczygiol, N.; Gawrońska, E.; Grosser, A. Symulacja numeryczna krzepnięcia kierowanego ochładzalnikami zewnętrznymi i wewnętrznymi. Arch. Foundry 2002, 2, 239-244.

4. Boettinger, W.J.; Coriell, S.R.; Greer, A.L.; Karma, A.; Kurz, W.; Rappaz, M.; Trivedi, R. Solidification microstructures: Recent developments, future directions. Acta Mater. 2000, 48, 43-70. [CrossRef]

5. Dantzig, J.A.; Rappaz, M. Solidification, 2nd ed.; EPFL Press: Lausanne, Switzerland, 2016.

6. Chong, K.P. Nanoscience and engineering in mechanics and materials. J. Phys. Chem. Solids 2004, 65, 1501-1506. [CrossRef]

7. Sika, R.; Rogalewicz, M.; Popielarski, P.; Czarnecka-Komorowska, D.; Przestacki, D.; Gawdzińska, K.; Szymański, P. Decision Support System in the Field of Defects Assessment in the Metal Matrix Composites Castings. Materials 2020, 13, 3552. [CrossRef]

8. Czarnecka-Komorowska, D.; Grześkowiak, K.; Popielarski, P.; Barczewski, M.; Gawdzińska, K.; Popławski, M. Polyethylene Wax Modified by Organoclay Bentonite Used in the Lost-Wax Casting Process: Processing-Structure-Property Relationships. Materials 2020, 13, 2255. [CrossRef]

9. Krolczyk, J.B.; Gapiński, B.; Krolczyk, G.M.; Samardžić, I.; Maruda, R.W.; Soucek, K.; Legutko, S.; Nieslony, P.; Javadi, Y.; Stas, L. Topographic inspection as a method of weld joint diagnostic. Teh. Vjesn. 2016, 23, 301-306. [CrossRef] 
10. Chong, K.P.; National Science Foundation, Arlington, VA, USA. Personal communication, 2009.

11. Boettinger, W.J. The Solidification of Multicomponent Alloys. J. Phase Equilibria Diffus. 2016, 37, 4-18. [CrossRef]

12. Rappaz, M. Modeling and characterization of grain structures and defects in solidification. Curr. Curr. Opin. Solid State Mater. Sci. 2016, 20, 37-45. [CrossRef]

13. Rappaz, M. Modelling of Solidification at Various Length Scales: From the Processes to the Microstructure and Defects; EUROPAM: Mainz, Germany, 2003.

14. Jacot, A.; Rappaz, M. A pseudo-front tracking technique for the modelling of solidification microstructures in multi-component alloys. Acta Mater. 2002, 50, 1909-1926. [CrossRef]

15. Gránásy, L.; Tóth, G.; Warren, J.A.; Podmaniczky, F.; Tegze, G.; Rátkai, L.; Pusztai, T. Phase-field modeling of crystal nucleation in undercooled liquids-A review. Prog. Mater. Sci. 2019, 106, 100569. [CrossRef]

16. Du, Q.; Jacot, A. A two-dimensional microsegregation model for the description of microstructure formation during solidification in multicomponent alloys: Formulation and behavior of the model. Acta Mater. 2005, 53, 3479-3493. [CrossRef]

17. Kapturkiewicz, W.; Fraś, E.; Burbelko, A.A. Dlaczego modelowanie jest w odlewnictwie potrzebne? Foundry Rev. 2005, 1, 15-23.

18. Stefanescu, D.M. Methodologies for Modeling of Solidification Microstructure and Their Capabilities. ISIJ Int. 1995, 35, 637-650. [CrossRef]

19. Rappaz, M.; Jacot, A.; Gandin, C.-A. Modeling of Dendritic Grain Formation During Solidification at the Level of Macro- and Microstructure. In Continuum Scale Simulation of Engineering Materials Fundamentals-Microstructures-Process. Applications; Raabe, D., Roters, F., Barlat, F., Chen, L.-Q., Eds.; Wiley-VCH: Weinheim, Germany, 2004; pp. 251-269. ISBN 3-527-30760-5. [CrossRef]

20. Souhar, Y.; De Felice, V.F.; Beckermann, C.; Combeau, H.; Založnik, M. Three-dimensional mesoscopic modeling of equiaxed dendritic solidification of a binary alloy. Comput. Mater. Sci. 2016, 112, 304-317. [CrossRef]

21. Khalajzadeh, V.; Beckermann, C. Simulation of Shrinkage Porosity Formation during Alloy Solidification. Met. Mater. Trans. A 2020, 51A, 2239-2254. [CrossRef]

22. Gandin, C.-A.; Chabron, C.; Rappaz, M. Stochastic Modelling of Solidification Grain Structure. ISIJ Int. 1995, 35, 651-657. [CrossRef]

23. Gandin, C.-A.; Rappaz, M. A Coupled Finite Element-Cellular Automaton Model for the Prediction of Dendritic Grain Structures in Solidification Processes. Acta Met. Mater. 1994, 42, 2233-2246. [CrossRef]

24. Lee, P.D.; Chirazi, A.; Atwood, R.C.; Wang, W. Multiscale modelling of solidification microstructures, including microsegregation and microporosity, in an Al-Si-Cu alloy. Mater. Sci. Eng. A 2004, 365, 57-65. [CrossRef]

25. Kim, S.-B.; Kweon, E.-S.; Ahn, S.-H.; Stefanescu, D.M. Development of a hybrid method for improved accuracy of mould filling computational models for castings. Int. J. Cast Met. Res. 2019, 32, 181-190. [CrossRef]

26. Jacot, A. A cellular automaton approach for the prediction of grain size in grain refined alloys. Iop Conf. Ser. Mater. Sci. Eng. 2020, 861, 012061. [CrossRef]

27. Karma, A.; Tourret, D. Atomistic to continuum modeling of solidification microstructures. Curr Opin Solid State Mater. Sci 2016, 20, 25-36. [CrossRef]

28. Heyvaert, L.; Bedel, M.; Založnik, M.; Combeau, H. Modeling of the coupling of microstructure and macrosegregation in a direct chill cast Al-Cu billet. Met. Mater. Trans. A 2017, 48, 4713-4734. [CrossRef]

29. Wang, C.Y.; Beckermann, C. Prediction of Columnar to Equiaxed Transition during Diffusion-Controlled Dendritic Alloy Solidification. Met. Mater. Trans. A 1994, 25A, 1081-1093. [CrossRef]

30. Ramirez, A.; Carrillo, F.; Gonzalez, J.L.; Lopez, S. Stochastic simulation of grain growth during continuous casting. Mater. Sci. Eng. A 2006, 421, 208-216. [CrossRef]

31. Jia, Y.; Zhao, D.; Li, C.; Bao, L.; Le, Q.; Wang, H.; Wang, X. Study on Solidification Structure Evolution of Direct-Chill Casting High Purity Copper Billet Using Cellular Automaton-Finite Element Method. Metals 2020, 10, 1052. [CrossRef]

32. Hajkowski, J.; Popielarski, P.; Ignaszak, Z. Cellular Automaton Finite Element method applied for microstructure prediction of aluminium casting treated by laser beam. Arch. Foundry Eng. 2019, 19, 111-118. [CrossRef]

33. Gurgul, D.; Burbelko, A.; Fras, E.; Guzik, E. Multiphysics and multiscale modelling of ductile cast iron solidification. Arch. Foundry Eng. 2010, 10, 35-40.

34. Burbelko, A.A.; Gurgul, D.; Wiktor, T. Analysis of Spherical Particles Size Distribution-Theoretical Basis. Arch. Foundry Eng. 2018, 18, 29-34. [CrossRef]

35. Burbelko, A.A.; Kapturkiewicz, W.; Gurgul, D.; Stręk, P. Modeling of the dendrite arms behavior during solidification. Arch. Foundry Eng. 2009, 9, 13-16.

36. Zhu, M.F.; Hong, C.P.; Stefanescu, D.M.; Chang, Y.A. Computational Modeling of Microstructure Evolution in Solidification of Aluminum Alloys. Met. Mater. Trans. B 2007, 38, 517-524. [CrossRef]

37. Beckermann, C.; Diepers, H.-J.; Steinbach, I.; Karma, A.; Tong, X. Modeling Melt Convection in Phase-Field Simulations of Solidification. J. Comput. Phys. 1999, 154, 468-496. [CrossRef]

38. Boettinger, W.J.; Warren, A.J.; Beckermann, C.; Karma, A. Phase-Field Simulation of Solidification. Annu. Rev. Mater. Res. 2002, 32, 163-194. [CrossRef]

39. Lu, Y.; Beckermann, C.; Karma, A. Convection effects in three-dimensional dendritic growth. In Proceedings of the ASME 2002 International Mechanical Engineering Congress and Exposition, New Orleans, LA, USA, 17-22 November 2002; ASME: New York, NY, USA, 2002; pp. 197-202. 
40. Nastac, L. Numerical Modeling of Solidification Morphologies and Segregation Patterns in Cast Dendritic Alloys. Acta Mater. 1999, 47, 4253-4262. [CrossRef]

41. Martorano, M.A.; Beckermann, C.; Gandin, Ch.-A. A Solutal Interaction Mechanism for the Columnar-to-Equiaxed Transition in Alloy Solidification. Met. Mater. Trans. A 2003, 34, 1657-1674. [CrossRef]

42. Gawroński, J.; Szajnar, J. Zmiany Strukturalne Wywołane Działaniem Zewnętrznego Pola Magnetycznego Podczas Krzepnięcia Odlewu. Solidif. Met. Alloy. 1986, 10, 115-128.

43. Ohno, A. Solidification: The Separation Theory and its Practical Applications; Springer: Berlin/Heidelberg, Germany, 1987; ISBN 978-3-540-18233-7. [CrossRef]

44. Tiller, W.A. The Science of Crystallization: Microscopic Interfacial Phenomena; Cambridge University Press: Cambridge, UK, 1991; ISBN 978-052-138-827-6.

45. Diepers, H.-J.; Beckermann, C.; Steinbach, I. Simulation of Convection and Ripening in a Binary Alloy Mush Using the Phase-Field Method. Acta Mater. 1999, 47, 3663-3678. [CrossRef]

46. Boukellal, A.K.; Debierre, J.-M.; Reinhart, G.; Nguyen-Thi, H. Scaling laws governing the growth and interaction of equiaxed Al-Cu dendrites: A study combining experiments with phase-field simulations. Materialia 2018, 1, 62-69. [CrossRef]

47. Yang, X.L.; Dong, H.B.; Wang, W.; Lee, P.D. Microscale simulation of stray grain formation in investment cast turbine blades. Mater. Sci. Eng. A 2004, 386, 129-139. [CrossRef]

48. Gandin, Ch.-A.; Desbiolles, J.-L.; Rappaz, M.; Thevoz, Ph. A Three-Dimensional Cellular Automaton-Finite Element Model for the Prediction of Solidification Grain Structures. Met. Mater. Trans. A 1999, 30, 3153-3165. [CrossRef]

49. Rappaz, M.; Gandin, C.-A. Probalistic Modelling of Microstrukture Formation in Solidification Processes. Acta Met. Mater. 1993, 41, 345-360. [CrossRef]

50. Gandin, Ch.-A. Modélisation stochastique de la solidification: Formation de structures de grains dendritiques. PhD Thesis, Ecole Polytechnique Fédérale de Lausanne, Lausanne, Switzerland, 1995. [CrossRef]

51. Gandin, Ch.-A.; Rappaz, M. A 3D cellular automaton algorithm for the prediction of dendritic grain growth. Acta Met. Mater. 1997, 45, 2187-2195. [CrossRef]

52. Ignaszak, Z.; Hajkowski, J. Prediction of CET-zone position using the Cellular Automaton-Finite Element method for Al-Si alloys castings. In Proceedings of the Fifth International Conference on Mathematical Modeling and Computer Simulations of Materials Technologies (MMT-2008), Ariel, Israel, 8-12 September 2008.

53. Jarry, P.; Rappaz, M. Recent advances in the metallurgy of aluminium alloys. Part I: Solidification and casting. C. R. Phys. 2018, 19. [CrossRef]

54. Kukliński, M.; Bartkowska, A.; Przestacki, D. Microstructure and selected properties of Monel 400 alloy after laser heat treatment and laser boriding using diode laser. Int. J. Adv. Manuf. Technol. 2018, 98, 3005-3017. [CrossRef]

55. Bartkowski, D.; Matysiak, W.; Bartkowska, A. Selected properties of laser cladding coatings shaped using Flow drill technology. MATEC Web Conf. 2017, 137, 05001. [CrossRef]

56. Bartkowski, D.; Bartkowska, A.; Jurči, P. Laser cladding process of Fe/WC metal matrix composite coatings on low carbon steel using Yb: YAG disk laser. Opt. Laser Technol. 2021, 136. [CrossRef]

57. Al-Sayed, S.; Hussein, A.; Nofal, A.; Hassab Elnaby, S.; Elgazzar, H. Characterization of a Laser Surface-Treated Martensitic Stainless Steel. Materials 2017, 10, 595. [CrossRef]

58. Krawiec, P.; Różański, L.; Czarnecka-Komorowska, D.; Warguła, Ł. Evaluation of the Thermal Stability and Surface Characteristics of Thermoplastic Polyurethane V-Belt. Materials 2020, 13, 1502. [CrossRef] [PubMed] 